\title{
The origin, source, and cycling of methane in deep crystalline rock biosphere
}

\author{
Riikka Kietäväinen ${ }^{1 *}$ and Lotta Purkamo ${ }^{2 *}$ \\ ${ }^{1}$ Geological Survey of Finland, Espoo, Finland, ${ }^{2}$ VTT Technical Research Centre of Finland, Espoo, Finland
}

OPEN ACCESS

Edited by:

Paul Bodelier,

Netherlands Institute of Ecology (NIOO-KNAW), Netherlands

Reviewed by:

Tillmann Lueders,

Helmholtz Zentrum München,

Germany

Sascha M. B. Krause,

University of Washington, USA

*Correspondence:

Rilkka Kietäväinen

Geological Survey of Finland, PO Box

96, 02151 Espoo, Finland

riikka.kietavainen@gtk.fi

Lotta Purkamo,

VTT Technical Research Centre of Finland, Tietotie 2, 02044 VTT, Espoo,

Finland

lotta.purkamo@vtt.fi

Specialty section:

This article was submitted to Terrestrial Microbiology,

a section of the journal

Frontiers in Microbiology

Received: 09 April 2015 Accepted: 02 July 2015 Published: 17 July 2015

Citation:

Kietäväinen R and Purkamo L (2015) The origin, source, and cycling of methane in deep crystalline rock biosphere. Front. Microbiol. 6:725. doi: 10.3389/fmicb.2015.00725
The emerging interest in using stable bedrock formations for industrial purposes, e.g., nuclear waste disposal, has increased the need for understanding microbiological and geochemical processes in deep crystalline rock environments, including the carbon cycle. Considering the origin and evolution of life on Earth, these environments may also serve as windows to the past. Various geological, chemical, and biological processes can influence the deep carbon cycle. Conditions of $\mathrm{CH}_{4}$ formation, available substrates and time scales can be drastically different from surface environments. This paper reviews the origin, source, and cycling of methane in deep terrestrial crystalline bedrock with an emphasis on microbiology. In addition to potential formation pathways of $\mathrm{CH}_{4}$, microbial consumption of $\mathrm{CH}_{4}$ is also discussed. Recent studies on the origin of $\mathrm{CH}_{4}$ in continental bedrock environments have shown that the traditional separation of biotic and abiotic $\mathrm{CH}_{4}$ by the isotopic composition can be misleading in substrate-limited environments, such as the deep crystalline bedrock. Despite of similarities between Precambrian continental sites in Fennoscandia, South Africa and North America, where deep methane cycling has been studied, common physicochemical properties which could explain the variation in the amount of $\mathrm{CH}_{4}$ and presence or absence of $\mathrm{CH}_{4}$ cycling microbes were not found. However, based on their preferred carbon metabolism, methanogenic microbes appeared to have similar spatial distribution among the different sites.

\footnotetext{
Keywords: abiotic methane, deep subsurface, Precambrian bedrock, carbon cycle, methanogenesis, methanotrophy, isotopic fractionation
}

\section{Introduction and Historical Perspective}

Methane is a key compound in the global carbon cycle. In the shallow subsurface $\mathrm{CH}_{4}$ is mainy produced by anaerobic digestion of organic matter. Deeper in the geological strata $\mathrm{CH}_{4}$ is found in large quantities within sedimentary formations and unconventional resources, such as shale gas, have also proven to be important reserves of $\mathrm{CH}_{4}$ (Arthur and Cole, 2014). Other sources of $\mathrm{CH}_{4}$ include methane hydrates and clathrates in deep lake sediments and seafloor (Walter et al., 2006; Ruppel, 2011; Kretschmer et al., 2015; Treat et al., 2015). In addition, $\mathrm{CH}_{4}$ is a dominant gas in many Precambrian continental bedrock formations (Fritz et al., 1987; Karus et al., 1987; Nurmi et al., 1988; Sherwood Lollar et al., 1993a,b; Ward et al., 2004; Sherwood Lollar et al., 2006; Pitkänen and Partamies, 2007; Hallbeck and Pedersen, 2008a; Stotler et al., 2010; Kietäväinen et al., 2013, 2014). 
Table 1 describes the carbon geochemistry of several continental study sites in Fennoscandia, South Africa, and North America within the depth range from few hundred meters down to $3.4 \mathrm{~km}$. Microbes involved in methane cycling have been detected in many of these sites.

The emerging interest in using stable bedrock formations for industrial purposes (e.g., nuclear waste disposal sites or carbon dioxide or natural gas storages) has increased the need for understanding the complete carbon cycling scheme in deep crystalline rock environments. $\mathrm{CH}_{4}$ can have effects on industrial utilization of the deep bedrock: It can promote growth of microorganisms in the subsurface by providing an ample source of energy and carbon. Increased microbial activity can lead to $\mathrm{pH}$ changes inducing corrosion and alteration of geochemistry resulting to mineral precipitation and scaling, or mobilization of hazardous compounds such as radiocarbon, thus damaging the infrastructure or imposing a risk to the environment. Therefore, research has been conducted for several years for example related to the long-term geological disposal of spent nuclear fuel to deep subsurface facilities in Canada, Sweden, USA, Finland, and Belgium (Stroes-Gascoyne and West, 1996; Pedersen, 1996; Fredrickson et al., 2004; Wang and Francis, 2005; Nyyssönen et al., 2012; Wouters et al., 2013). These studies have provided not only an understanding of the microbial risks, but also knowledge of the active microbial communities living in deep geological surroundings. However, many aspects of origin, source, and cycling of $\mathrm{CH}_{4}$ in deep continental bedrock environments still remain poorly understood. These include sources of carbon and hydrogen in different rock formations, importance of microbial involvement, timescales and quantities of $\mathrm{CH}_{4}$ production, and movements within and fluxes from bedrock.

Potential formation pathways of $\mathrm{CH}_{4}$ in deep crystalline bedrock are presented in Figure 1. In principle, hydrocarbons can form via two major ways: from break-up of organic matter ("from big to small") or due to organic synthesis of small $\mathrm{C}$ and $\mathrm{H}$ bearing molecules and further polymerization of these molecules into higher hydrocarbons ("from small to big"). The first way includes the formation of thermogenic $\mathrm{CH}_{4}$ and microbial aceticlastic methanogenesis. The latter includes abiotic organic synthesis, such as Fischer-Tropsch or Sabatier type reactions, and microbial hydrogenotrophic methanogenesis. Thus, both ways can be facilitated by microorganisms but may also occur inorganically. Not only is $\mathrm{CH}_{4}$ produced but is also consumed within bedrock by anaerobic and aerobic processes with and without microorganisms.

The occurrence and major sources for abiotic $\mathrm{CH}_{4}$ was discussed in a recent review by Etiope and Sherwood Lollar (2013) and microbial biodiversity in terrestrial subsurface environments by Fredrickson and Balkwill (2006). Yet it has been over a decade since the microbial $\mathrm{CH}_{4}$ cycling in deep subsurface has been reviewed (Kotelnikova, 2002). Since then the scientific community has been pushing the understanding of deep carbon cycling to new frontiers. Recent advances in molecular biological methods, such as high-throughput sequencing and "omics" methods have expanded the knowledge of microbial community composition and functions in the deep biosphere (Teske and Biddle, 2008; Brazelton et al., 2012;
Nyyssönen et al., 2014). The development of new computational methods for processing, mining and assessing metagenomic data has provided tools for handling the vast amount of data generated (e.g., Schloss et al., 2009; Caporaso et al., 2010; Langille et al., 2013). Some novel methods have been used to assess the microbial ecology of the deep terrestrial subsurface. For example, a single-species ecosystem fully independent from surface life and photosynthesis, gaining energy from sulfate reduction was discovered at $2.8 \mathrm{~km}$ depth from South African gold mine in 2008 by Chivian et al. with metagenomics approach (Chivian et al., 2008). Nyyssönen et al. (2014) used high-throughput amplicon sequencing and metagenomics for characterization of the $2.5 \mathrm{~km}$ Outokumpu Deep Drill Hole microbial communities in Finland.

In this review we aim to revise methane cycling within continental bedrock, as well as to provide an overview of methodological and conceptual advances in this field with an emphasis on microbiology. Diversity and variation of geochemical and microbiological characteristics in $\mathrm{CH}_{4}$ containing deep bedrock environments are introduced through several case studies. Finally, we point out some key remaining unknowns and give suggestions for further research.

\section{Geological Methane}

Two main types of geological $\mathrm{CH}_{4}$ are depicted in Figure $\mathbf{1}$ which summarizes $\mathrm{CH}_{4}$ cycling in the continental deep biosphere. Of these, thermogenic $\mathrm{CH}_{4}$ is formed from the break-up of organic matter at elevated temperatures and pressures. This is thought to be the dominant $\mathrm{CH}_{4}$ type in sedimentary basins and is the economically most important source of natural gas (e.g., Galimov, 1988; Milkov, 2011). However, even though some rocks found in continental shields, most notably black schists, also originate from organic rich material, the occurrence and preservation of "fossil" organic compounds in highly metamorphosed crystalline rocks is questionable (but see Karus et al., 1987 and Taran et al., 2011 for examples of organic compounds such as bitumen found in metamorphic and even igneous rocks of Archaean to Proterozoic age). Instead, carbon is mostly found in the form of graphite and carbonate minerals. Thus, and taking into account the low temperatures presently prevailing in continental shield sites (Table 1), any thermogenic $\mathrm{CH}_{4}$ component would likely be relic. Where hydrocarbonbearing sedimentary formations are nearby, thermogenic $\mathrm{CH}_{4}$ may find its way into metamorphic and igneous rocks by diffusion or advective flow (Etiope and Martinelli, 2002 and references therein).

Probably the more important source of geological $\mathrm{CH}_{4}$ in crystalline bedrock environments is abiotic. This refers to $\mathrm{CH}_{4}$ that has formed from inorganic compounds without the involvement of biological activity. Abiotic $\mathrm{CH}_{4}$ can be either magmatic or produced in water-rock reactions, the latter of which may take place even at low temperatures and pressures (Etiope and Sherwood Lollar, 2013). Within the habitable zone in the upper crust, high temperature abiotic $\mathrm{CH}_{4}$ may be provided by a gas flux from deeper, hotter regions (Figure 1) or leak from fluid inclusions. However, abiotic $\mathrm{CH}_{4}$ can also potentially form in situ in low temperature processes which include Sabatier and 


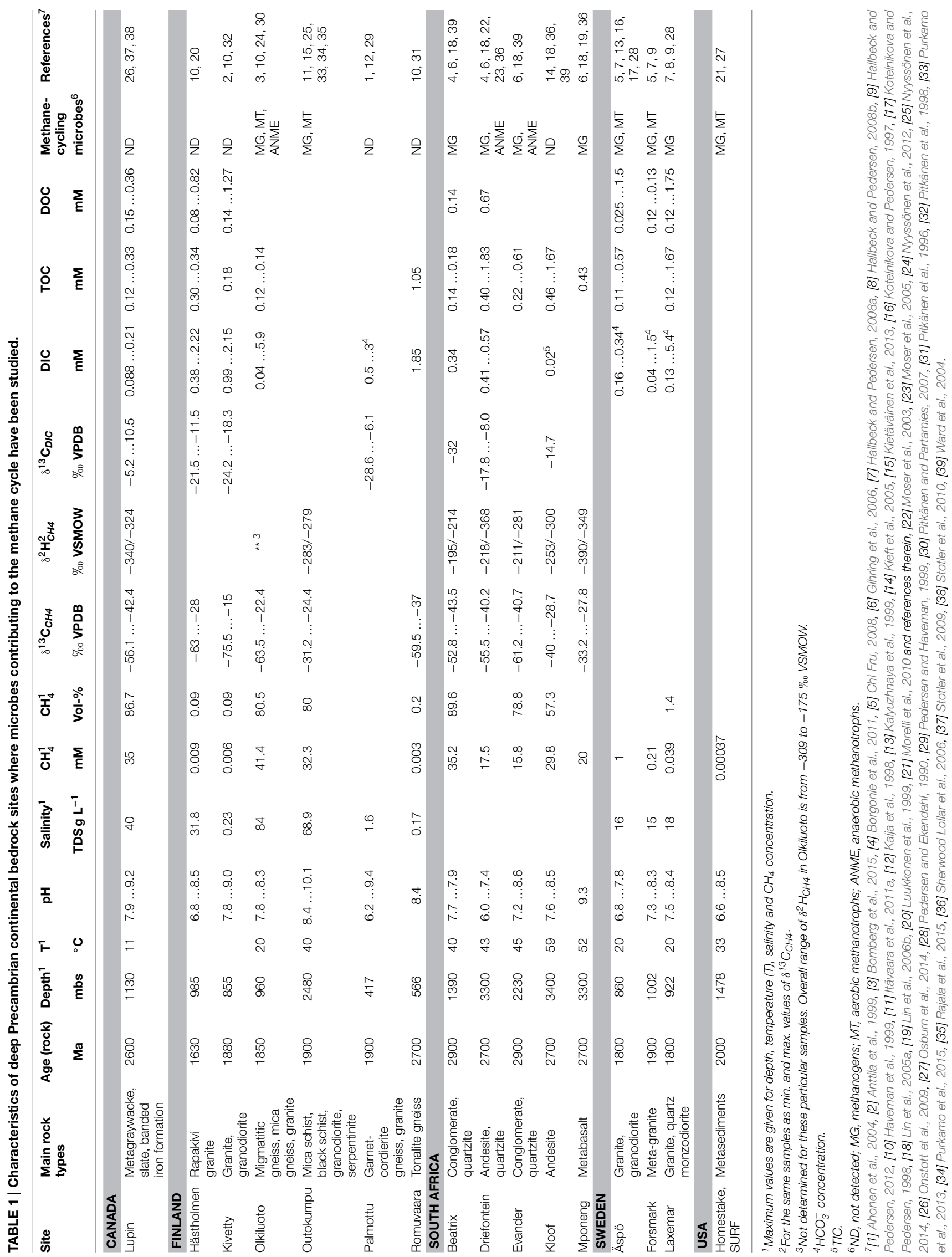




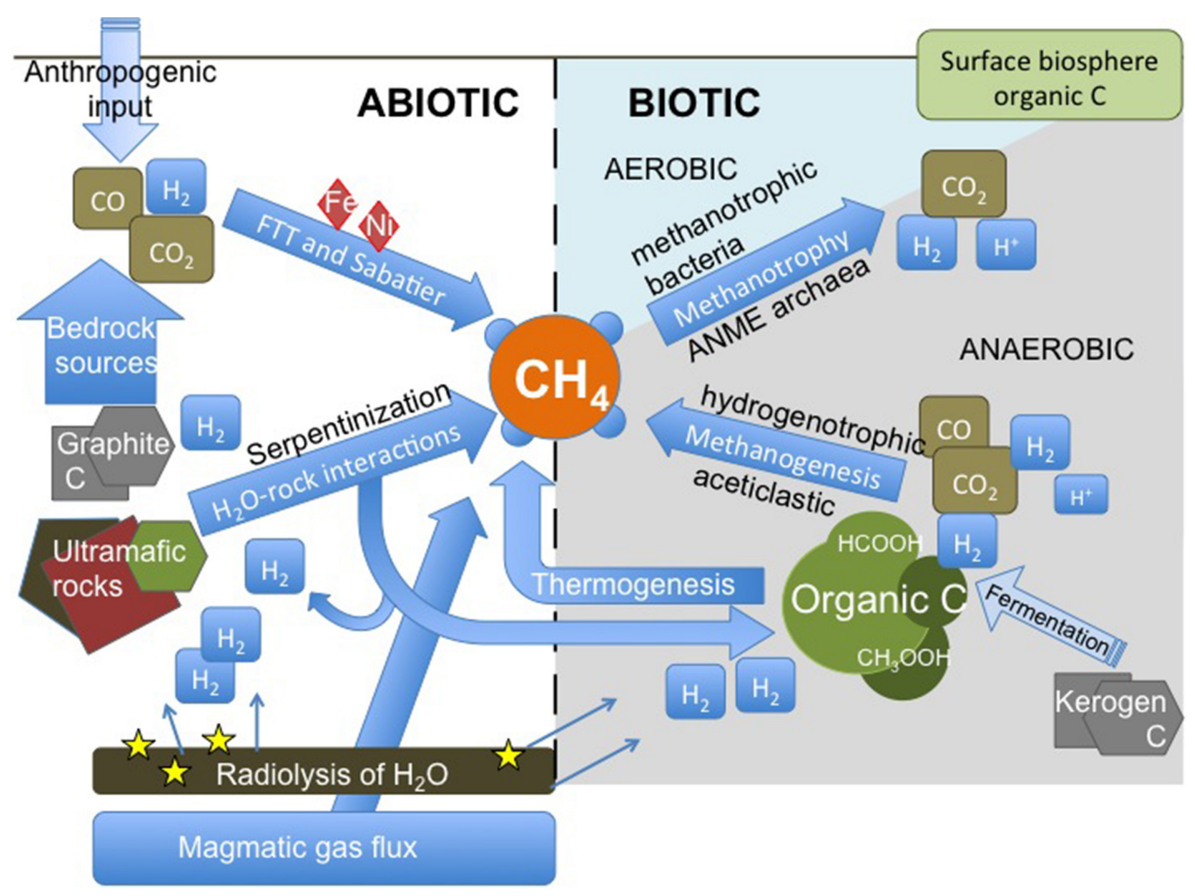

FIGURE 1 | Methane cycling scheme in the deep continental biosphere. Methane can originate either from low temperature abiotic reactions in the upper crust, as a gas flux deeper from the crust or mantle or as a result of microbial activity. $\mathrm{CO}_{2}$ and organic matter are common carbon sources, while hydrogen can be derived from breakdown of water in radiolysis, from water-rock interactions or from microbial metabolism. Biological consumption of $\mathrm{CH}_{4}$ can be divided to aerobic and anaerobic methane oxidation, the former being more abundant in shallower depths and the latter in greater depths. Hydrogenotrophic methanogens use inorganic carbon for the production of $\mathrm{CH}_{4}$, as aceticlastic or methylotrophic methanogens use organic carbon molecules, such as formate or acetate. Bacterial fermentation of complex carbon-containing materials, such as kerogen, may produce hydrogen and small organic molecules for methanogens. FIT, Fischer-Tropsch type synthesis of hydrocarbons; ANME archaea, anaerobic methanotrophic archaea.
Fischer-Tropsch type (FTT) synthesis of $\mathrm{CH}_{4}$ (Jacquemin et al., 2010; McCollom et al., 2010; Etiope and Sherwood Lollar, 2013; Zhang et al., 2013). These reactions are most likely catalyzed by metals, such as $\mathrm{Fe}$ and $\mathrm{Ni}$ or certain mineral phases, such as clay minerals (Jacquemin et al., 2010; McCollom et al., 2010; McCollom, 2013; Etiope and Ionescu, 2014). More detailed description of the possible mechanisms of abiotic $\mathrm{CH}_{4}$ formation can be found in recent reviews by Etiope and Sherwood Lollar (2013) and McCollom (2013).

\section{Microbial Contribution to $\mathrm{CH}_{4}$ Budget in the Bedrock}

\section{Methanogenesis}

Microbial methanogenesis is constrained to the domain Archaea. Methanogens can be divided to two groups depending on their $\mathrm{CH}_{4}$ production pathways: chemolithoautotrophic methanogens utilizing solely $\mathrm{CO}_{2}$ and $\mathrm{H}_{2}$ for their cellular building blocks and energy production and organotrophic methanogens utilizing an array of different carbon molecules containing methyl group such as acetate, methanol, methylamines, and methylsulfides as substrates (Figure 1) (e.g. Garcia et al., 2000; Thauer et al., 2008; Ferry, 2010, 2011).
Methanogens thrive in many environments considered extreme from an anthropocentric point of view. These include deep, dark, isolated, and nutrient-depleted subsurface environments. Typically methanogenic archaea can be found in anaerobic environments where all other electron acceptors but $\mathrm{CO}_{2}$ are limiting. Methanogenic archaea are an essential part of the microbial communities in deep continental crystalline biosphere as several studies from over the last 20 years have demonstrated (Table 1 and e.g., Sherwood Lollar et al., 1993a; Kotelnikova and Pedersen, 1997, review by Kotelnikova, 2002).

Today, seven methanogenic archaeal orders are known: Methanopyrales, Methanococcales, Methanobacteriales, Methanocellales, and Methanomicrobiales (all of which depend on $\mathrm{H}_{2}$ and $\mathrm{CO}_{2}$ and some of them can utilize formate as carbon source) and Methanosarcinales (with more versatile carbon metabolism) (Thauer et al., 2008; Costa and Leigh, 2014). In addition to these, the representatives of the recently proposed seventh order "Methanoplasmatales" are methylotrophic methanogens utilizing methanol, methylamines, and $\mathrm{H}_{2}$ (Paul et al., 2012; Borrel et al., 2013). Methanogenesis involves several enzymes and cofactors, resulting in a complex metabolic process.

In all methanogenic pathways, the final step in production of methane is performed by methyl-coenzyme $\mathrm{M}$ reductase. The gene morA, coding for the alpha subunit of this enzyme, 
has been used widely as a marker gene for methanogenesis in various environmental studies (e.g., Luton et al., 2002; Chin et al., 2004; Dhillon et al., 2005; Juottonen et al., 2006). Heterodisulfide reductase, which is required in the final step of methanogenesis, can be either membrane-bound (Methanosarcinales) or cytoplasmic (other methanogens). It has been observed that Methanosarcinales with membrane bound cytochromes have higher growth yields but methanogens with cytoplasmic heterosulfide reductase enzyme have lower threshold level for $\mathrm{H}_{2}$ partial pressure. Consequently, methanogenesis from carbon dioxide is dependent on hydrogen ion concentration, while electrons from the methanogenesis process are bound to hydrogen ions to drive ATP synthase and ultimately produce the energy for the methanogens (Thauer et al., 2008). Due to the lower threshold level for $\mathrm{H}_{2}$, hydrogenotrophic methanogens can outcompete Methanosarcinales -methanogens in environments with low hydrogen concentration. There are more hydrogenotrophic methanogens than methanogens utilizing methylotrophic or aceticlastic pathways (Liu and Whitman, 2008). Whether this is because of the hydrogenotrophic $\mathrm{CO}_{2}$-pathway is more favorable energetically, or hydrogenotrophic pathway being more ancient and thus has had more time to spread and diversify in the archaeal populations, or there has been more success in cultivating hydrogenotrophic methanogens, is still debatable.

\section{Methane Oxidation}

In addition to methane-producing archaea, the deep subsurface environments host microbes utilizing $\mathrm{CH}_{4}$ for their sole source of carbon and energy, called methanotrophic microorganisms (Figure 1). Electron acceptors can vary from oxygen to sulfate, nitrate and nitrite, iron and manganese (Hanson and Hanson, 1996; Orphan et al., 2002; Raghoebarsing et al., 2006; Beal et al., 2009; Knittel and Boetius, 2009; Ettwig et al., 2010; Haroon et al., 2013). As most of the deep crystalline bedrock habitats are mainly anaerobic, other electron acceptors than oxygen could be more relevant in these environments. Nevertheless, the detection of both aerobic and anaerobic methanotrophs from deep crystalline bedrock prove that both of these microbial groups have a niche in the depths (Table 1) (Kalyuzhnaya et al., 1999; Chi Fru, 2008; Hirayama et al., 2011; Nyyssönen et al., 2012; Bomberg et al., 2015; Purkamo et al., 2015; Rajala et al., 2015). In addition, aerobic methylotrophs appear to frequently occupy geological lignite and coal formations that are usually considered anaerobic, at depths of over $1 \mathrm{~km}$ (Mills et al., 2010; Stępniewska et al., 2013, 2014). Anaerobic methanotrophic archaea (ANME archaea) are frequently found from deep subseafloor sediments (e.g., Mills et al., 2003; Knittel et al., 2005; Lazar et al., 2011a,b) and even in deeply buried Juan de Fuca Ridge flank basalts (Lever et al., 2013). They are more rarely encountered in continental deep biosphere. However, ANME archaea have been recently detected in groundwaters in Olkiluoto of the Fennoscandian Shield, Finland (Nyyssönen et al., 2012; Bomberg et al., 2015).

\section{Aerobic Methane Oxidation}

Representatives of aerobic methanotrophic bacteria can be found from alpha- and gamma-proteobacterial families and class Verrucomicrobiae. Aerobic methanotrophs use two types of biosynthesis pathways for incorporation of methane, either serine pathway or ribulose monophosphate pathway (RuMP) (Chistoserdova et al., 2009; Nazaries et al., 2013).

The aerobic methanotrophic bacteria have distinct intracellular membrane features. These intracellular membranes are arranged as stacks of disc-shaped features or as paired membranes following the brim of the cell interior. Methane monooxygenase, the key enzyme of aerobic $\mathrm{CH}_{4}$ oxidation is located in these intracellular membrane structures. Methane monooxygenase mediates the first step of methanotrophy by oxidation of $\mathrm{CH}_{4}$ to methanol. Two types of methane monooxygenases exist: membrane-bound particulate MMO, which is the common type and soluble cytoplasmic MMO that is found irregularly in a few methanotrophic strains. Soluble methane monooxygenase can oxidize a wide range of different types of substrates from simple alkanes to cyclic compounds, thus evoking industrial interest (Bowman, 2006).

\section{Anaerobic Oxidation of Methane (AOM)}

All but one currently recognized anaerobic methanotrophs are archaea. The single exception is a bacterium Methylomirabilis oxyfera, which will be discussed in the next paragraph. Anaerobic methanotrophic archaea often referred to as ANME archaea usually live in a symbiotic relationship with sulfate reducers and are therefore abundant in sulfatemethane transition zones (SMTZ). SMTZs can be found in all anaerobic aquatic ecosystems where sulfate is available, such as marine sediments and deep terrestrial crystalline bedrock formations (e.g., Knittel and Boetius, 2009; Bomberg et al., 2015). ANME-1 and ANME-2 groups are usually associated with deltaproteobacterial Desulfosarcina and Desulfococcus. There is limited evidence that some ANME-2 archaea can form symbiotic relationships with alpha-proteobacterial Sphingomonas sp. or with betaproteobacterial Burkholderia sp. (Orphan et al., 2001, 2002; Knittel and Boetius, 2009). In addition, ANME-2d archaea have been demonstrated to oxidize $\mathrm{CH}_{4}$ and reduce nitrate in co-culture with an anaerobic ammonia oxidizer Kuenenia sp. (Haroon et al., 2013). Iron and manganese oxide minerals can be used as electron acceptors for anaerobic methane oxidation (Beal et al., 2009). ANME-3 archaea are typically associated with Desulfobulbus -type of sulfate reducers (Knittel and Boetius, 2009).

The only bacterial representative of an anaerobic methane oxidizer was found in anaerobic sediment from a Dutch canal and is candidatively named Methanomirabilis oxyfera (Ettwig et al., 2010). These peculiar bacteria grow anaerobically reducing nitrite to dinitrogen by nitric oxide dismutation simultaneously producing oxygen as an intermediate during this process within the cell. Oxygen is then used in the aerobic oxidation of $\mathrm{CH}_{4}$ to methanol with methane monooxygenase inside the cell.

The biochemical mechanism of anaerobic methane oxidation remains elusive. One hypothesis is that ANME archaea are reversing the methanogenic pathway and taking into use the key enzymes of this pathway. Released hydrogen from this process is removed by reducing electron acceptors such as sulfate by the syntrophic partner of ANMEs (Hallam et al., 
2004; Knittel and Boetius, 2009). Results from metagenomic studies have fortified the reverse methanogenesis hypothesis (Krüger et al., 2003; Meyerdierks et al., 2005). Another suggested mechanism is acetogenic methanotrophy, in which acetate and hydrogen are produced from two molecules of $\mathrm{CH}_{4}$, or from $\mathrm{CO}_{2}$ and $\mathrm{CH}_{4}$ and subsequently consumed by sulfate reducing bacteria (SRB). Yet another proposed hypothesis involves $\mathrm{CO}_{2}$ reducing, methane-oxidizing archaea producing methyl sulfides following a pathway similar to methanogenesis. In this methylogenesis model, methyl groups are transferred to sulfide allowing the regeneration of coenzyme M. SRB capable of utilizing methyl sulfides are crucial partner in these type of AOM consortiums (review by Caldwell et al., 2008 and references within). While SRB have in general a significant role in AOM, a recent study by Milucka et al. (2012) showed that methanotrophic ANME-2 archaea can perform dissimilatory sulfate reduction without the syntrophic sulfate-reducing bacterial partner.

\section{Origin of Substrates for Methanogenesis in Deep Crystalline Rock Biosphere}

Biological production and consumption of $\mathrm{CH}_{4}$ in deep crystalline bedrock is illustrated on the right in Figure 1. Abiotically produced carbon dioxide and hydrogen provide a useful source of carbon and energy for chemolithoautotrophic methanogens (Pedersen, 1997, 2000; Chapelle et al., 2002; Nealson et al., 2005; Schrenk et al., 2013). Within crystalline bedrock $\mathrm{H}_{2}$ needed for autotrophic $\mathrm{CH}_{4}$ synthesis can be produced during water-rock interactions such as serpentinization and other iron oxidation reactions (McCollom and Bach, 2009; Neubeck et al., 2011; Mayhew et al., 2013). It can also be produced through the dissociation of water molecules by energy released from radioactive decay, i.e., in radiolysis (Vovk, 1987; Lin et al., 2005a,b). The source of hydrogen may also be microbial (reviews by e.g., Nandi and Sengupta, 1998; Wang and Wan, 2009). Fermentative bacteria producing $\mathrm{H}_{2}$, such as clostridia have been detected in several deep continental rock formations (e.g., Moser et al., 2003; Rastogi et al., 2010; Itävaara et al., 2011b; Purkamo et al., 2013; Schrenk et al., 2013). Overall, $\mathrm{H}_{2}$ is common in these environments (Sherwood Lollar et al., 2014). Inorganic carbon can be found as carbonate minerals, graphite, and dissolved in groundwater (DIC). The speciation of DIC is controlled by $\mathrm{pH}$. In alkaline conditions, typical of deep groundwaters within crystalline rocks, DIC is commonly found in the form of bicarbonate $\left(\mathrm{HCO}_{3}^{-}\right)$and the concentrations may be quite low (Table 1).

In addition to inorganic carbon, methanogens can utilize organic compounds possibly produced in abiotic reactions, such as serpentinization of olivine-bearing ultramafic rocks (Lang et al., 2012). This principle can be turned inside out; in a recent review, Schrenk et al. (2013) suggested that heterotrophs might be the primary producers in serpentinizing environments. Thus, these heterotrophs utilizing organic materials (produced in abiotic reactions in deep Earth's crust or mantle) biologically produce inorganic end-products such as $\mathrm{H}_{2}$ and $\mathrm{CO}_{2}$. These can be used by organisms considered autotrophic, such as hydrogenotrophic methanogens.
Methanogenic archaea can also have the same function in the deep biosphere as in surface ecosystems, i.e., contributing to the degradation of organic matter in anaerobic conditions. Crystalline rock formations may contain refractory organic carbon materials such as kerogen or bitumoids for example in interlayers of black shales or black schist (Karus et al., 1987; Taran et al., 2011). During the formation of these rocks through diagenesis and maturation of sedimentary organic matter, carbon content, and aromaticity increase and volatile hydrocarbons usually migrate away (e.g., Strąpoć et al., 2011; Buseck and Beyssac, 2014). Further increase in temperature during metamorphosis will eventually turn the residual carbonaceous matter into graphite.

There are reports of microbes utilizing organic material trapped in sedimentary rocks such as shales and sandstones. Kerogen of black shales can be the sole carbon source for heterotrophs, such as Clostridium -type of bacteria, which in turn can support methanogenesis through the production of substrates for methanogens (Krumholz et al., 1997; Petsch et al., 2001, 2005). For example, clostridial fermenters can provide $\mathrm{H}_{2}$ and carbon to methanogens in a syntrophic consortium (Kimura et al., 2010; Rosewarne et al., 2013a,b). Thus, methanogens living in a syntrophic relationship with specialized bacteria can mediate anaerobic biodegradation of refractory complex compounds comparable to those found within crystalline bedrock (Strąpoć et al., 2011 and references within).

Fungal contribution to degradation of refractory material, such as organic polymers and polyaromatic hydrocarbons is well known (e.g., Haritash and Kaushik, 2009; Harms et al., 2011). In addition, fungal degradation of refractory organic matter of black shale has been demonstrated (Wengel et al., 2006). As the presence of fungi in deep Fennoscandian bedrock has been verified (Ekendahl et al., 2003; Sohlberg et al., 2015), fungi with the capacity for degradation of refractory and ancient organic and inorganic materials and efficient elemental cycling in addition to bioweathering ability might play a role in providing carbon sources for microbial methanogenesis in deep continental crystalline bedrock environments.

Organic matter from dead microbial biomass is an additional source of carbon in deep biosphere. Bacteriophages are present in deep crystalline bedrock groundwater. If these viruses are active and lytic, they can control the numbers of living microorganisms and therefore increase the dead cell mass in the deep subsurface (Kyle et al., 2008). Recently, Pedersen (2013) concluded that bacteriophages control the cell numbers in flow cells operating in in situ conditions in deep crystalline bedrock. The cell number in the flow cells never exceeded the cell densities observed in pristine groundwater (Pedersen, 2013).

Carbon sources for biological $\mathrm{CH}_{4}$ cycling can be anthropogenic and derived from the surface environments, such as in deep subsurface storage facilities for carbon dioxide or oil. Introduction of such carbon sources to microbial communities in the deep subsurface might induce a formidable activation of dormant microbes as Rajala et al. (2015) demonstrated. $\mathrm{H}_{2}$ can be released through a chemical reaction between freshly crushed rock and water for example during drilling and blasting of rock (Kita et al., 1982), or oxidation of metals 
such as iron casing which is often used to support drill hole walls.

To summarize, $\mathrm{H}_{2}$ seems to be abundant and available in continental crust (Sherwood Lollar et al., 2014). Despite the several possible sources of organic carbon in the crystalline rock formations discussed above, organic carbon is either absent, scarce or available only as a refractory material (Fredrickson et al., 1997; Fredrickson and Balkwill, 2006). Likewise, concentrations of dissolved inorganic carbon in deep bedrock formations are commonly low (Table 1). Thus, it might be carbon which actually limits the formation of $\mathrm{CH}_{4}$ and other hydrocarbons in continental bedrock.

\section{Geochemical Methods to Study Origin, Source, and Cycling Of $\mathrm{CH}_{4}$ - Principles and Limitations}

\section{Stable Isotope Composition of $\mathbf{C H}_{\mathbf{4}}$}

The attempts to separate different $\mathrm{CH}_{4}$ sources are mainly based on the isotopic composition of $\mathrm{CH}_{4}$. Typically this includes the determination of stable isotope ratios of carbon $\left({ }^{13} \mathrm{C} /{ }^{12} \mathrm{C}\right)$ and hydrogen $\left({ }^{2} \mathrm{H} /{ }^{1} \mathrm{H}\right.$, also called $\mathrm{D} / \mathrm{H}$ where $\mathrm{D}$ stands for deuterium) separately. The resulting isotopic compositions are commonly reported using $\delta$-notation per mill $(\% 0)$ relative to the isotopic composition of $\mathrm{H}$ and $\mathrm{C}$ in sea water (VSMOW, Vienna Standard Mean Ocean Water and VPDB, Vienna Pee Dee Belemnite):

$$
\begin{aligned}
\delta^{2} \mathrm{H} & =\left(\frac{\left({ }^{2} H /{ }^{1} H\right)_{\text {sample }}}{\left({ }^{2} H /{ }^{1} H\right)_{\text {VSMOW }}}-1\right) \times 1000 \\
\delta^{13} \mathrm{C} & =\left(\frac{\left({ }^{13} \mathrm{C} /{ }^{12} C\right)_{\text {sample }}}{\left({ }^{13} \mathrm{C} /{ }^{12} C\right)_{V P D B}}-1\right) \times 1000
\end{aligned}
$$

Fundamentals of stable isotope methods in geochemistry can be found from books by Clark and Fritz (1997) and Hoefs (2004). In brief, the isotopic composition of $\mathrm{CH}_{4}$ (or any chemical substance) is controlled by equilibrium and kinetic isotope effects, which arise from equilibrium isotope exchange and differences in reaction rates, respectively. Equilibrium isotope effects are mainly dependent on temperature. Kinetic fractionation is related to incomplete and unidirectional reactions such as those associated with microbial metabolism, and will lead to the depletion of lighter isotopes $\left({ }^{12} \mathrm{C}\right.$ and $\left.{ }^{1} \mathrm{H}\right)$ in the reaction product. These principles also form the basis for traditional classification of $\mathrm{CH}_{4}$ with $\delta^{13} \mathrm{C}$ vs. $\delta^{2} \mathrm{H}$ diagram (Schoell, 1980; Whiticar, 1999; Etiope and Sherwood Lollar, 2013; Etiope and Schoell, 2014).

The isotopic composition of $\mathrm{CH}_{4}$ is ultimately dependent on the starting material(s) and is further affected by microbial activity, openness of the system, temperature and time, to name a few. Along with increasing amount of data from various settings, it has become clear that $\mathrm{CH}_{4}$ from different origins may have similar isotopic composition. For example, unusual ${ }^{13} \mathrm{C}$ enriched microbial $\mathrm{CH}_{4}$ has been found from saline substrate limited environments (Kelley et al., 2012; Tazaz et al., 2013). Carbon limited conditions were also thought to be responsible for ${ }^{13} \mathrm{C}$ enriched metabolic products found from the Lost City Hydrothermal Field by Bradley et al. (2009). Valentine et al. (2004a) found that the fractionation associated with methanogenesis was correlated with temperature and metabolic rate. Likewise, abiotic $\mathrm{CH}_{4}$ may have a wide range of isotopic compositions. When compared to both microbial and thermogenic $\mathrm{CH}_{4}$, abiotic $\mathrm{CH}_{4}$ is typically enriched in ${ }^{13} \mathrm{C}$ (Etiope and Sherwood Lollar, 2013). However, abiotic $\mathrm{CH}_{4}$ produced in laboratory experiments has been rather depleted in ${ }^{13} \mathrm{C}$, down to around $-50 \%$ VPDB (Horita and Berndt, 1999; Taran et al., 2007).

Difference in the source of hydrogen (methyl group vs. water) forms the basis for separating aceticlastic from autotrophic microbial $\mathrm{CH}_{4}$ by means of hydrogen isotopic composition of $\mathrm{CH}_{4}$ (Sugimoto and Wada, 1995; Whiticar, 1999). Hydrogenase enzymes are known to rapidly equilibrate the isotopic compositions of $\mathrm{H}_{2}$ and $\mathrm{H}_{2} \mathrm{O}$ (Sugimoto and Wada, 1995; Valentine et al., 2004b). Furthermore, hydrogen isotope fractionation in the system $\mathrm{CH}_{4}-\mathrm{H}_{2} \mathrm{O}-\mathrm{H}_{2}$ can be used as a thermometer in a system where isotopic equilibrium has been attained, or it may help to reveal the amount of kinetic fractionation caused by biological processes (Bradley and Summons, 2010; Suda et al., 2014).

After formation, the isotopic composition of $\mathrm{CH}_{4}$ may change as the result of isotope exchange and equilibration, kinetic fractionation by abiotic or microbial oxidation (either aerobic or anaerobic) or migration (e.g., Coleman et al., 1981; Whiticar, 1999; Etiope et al., 2011). Compared to carbon, information on the $\mathrm{CH}_{4}$ source carried by hydrogen may be more easily lost by isotope exchange, especially when geological time scales are considered (Ni et al., 2011; Reeves et al., 2012). A further complication is brought up by mixing of $\mathrm{CH}_{4}$ originating from different sources.

\section{Co-existing $\mathrm{CO}_{2}$ and $\mathrm{C}_{2+}$ Hydrocarbons}

$\mathrm{CO}_{2}$ is usually a minor constituent in deep groundwaters within crystalline bedrock and, because of high $\mathrm{pH}$ typical for these environments, is mainly found in its dissolved form as $\mathrm{HCO}_{3}^{-}$ (e.g., Clark and Fritz, 1997; Frape et al., 2003). Nevertheless, considering $\mathrm{CO}_{2}$ is a potential carbon source for both microbial and abiotic $\mathrm{CH}_{4}$, it would be essential to know its isotopic composition (or the isotopic composition of DIC at least) in order to study the origin of $\mathrm{CH}_{4} \cdot{ }^{13} \mathrm{C}$ depleted DIC has also been used as an indication of microbial $\mathrm{CH}_{4}$ oxidation as kinetic fractionation caused by this process will favor depletion of ${ }^{13} \mathrm{C}$ in the product $\mathrm{CO}_{2}$ (Kotelnikova, 2002; Onstott et al., 2006). When recorded in minerals, such as calcite, this isotopic shift has been used for tracing carbon cycling in the past (e.g., Schidlowski, 2001; Drake and Tullborg, 2009; Sahlstedt et al., 2010).

Information on the origin and cycling of $\mathrm{CH}_{4}$ may also be obtained by comparing the abundance of $\mathrm{CH}_{4}$ to longer chained ("higher" or $\mathrm{C}_{2+}$ ) hydrocarbons. Longer chained hydrocarbons most commonly found in deep groundwaters within crystalline rocks are ethane and propane (Fritz et al., 1987; Nurmi et al., 1988; Sherwood Lollar et al., 1993a,b; Haveman et al., 1999; Ward et al., 2004; Kietäväinen et al., 2013). As microbial processes 
produce almost solely $\mathrm{CH}_{4}$ and not higher hydrocarbons, the ratio between $\mathrm{CH}_{4}$ and $\mathrm{C}_{2+}$ is very high $\left(>10^{3}\right)$, while $\mathrm{CH}_{4}$ produced by thermogenic break-up of organic matter tends to contain significant amounts of $\mathrm{C}_{2}$ compounds (e.g., Whiticar, 1999). Hydrocarbon formation due to abiotic organic synthesis at geologically relevant conditions is more poorly constrained (McCollom, 2013). Formation of longer chained alkanes and alkenes is a typical feature of FTT synthesis (e.g., Taran et al., 2007; McCollom et al., 2010; Zhang et al., 2013). However, no longer chained hydrocarbons were formed in the low temperature $(298 \mathrm{~K})$ FTT experiment conducted by Jacquemin et al. (2010) using $\mathrm{CO}_{2}$ and $\mathrm{H}_{2}$ as starting materials. The study by Horita and Berndt (1999) also suggest that the $\mathrm{CH}_{4}$ to $\mathrm{C}_{2+}$ ratio of abiotic gas might be closer to that of microbial than thermogenic gas. To summarize, variation in the $\mathrm{CH}_{4}$ to $\mathrm{C}_{2+}$ ratio of abiotic gas should be expected. Moreover, mixing of gases originating from different sources as well as microbial and inorganic reactions are capable of modifying the $\mathrm{CH}_{4}$ to $\mathrm{C}_{2+}$ ratio. For example, the ratio will be increased by both abiotic and microbial oxidation of $\mathrm{CH}_{4}$. Decrease in the ratio will take place if longer hydrocarbons are consumed in microbial $\mathrm{CH}_{4}$ production (Zengler et al., 1999).

A further approach is to compare the isotopic compositions of longer chained hydrocarbons and $\mathrm{CH}_{4}$. In typical thermogenic gas, the isotopic composition of carbon proceeds toward more ${ }^{13} \mathrm{C}$ depleted compositions in the series propane-ethane-methane while isotopic depletion of ${ }^{13} \mathrm{C}$ along with increasing chain length (reversed pattern) has been suggested to characterize abiotic hydrocarbons (e.g., Sherwood Lollar et al., 2002; Zhang et al., 2013). Both trends can be explained by reaction kinetics, as lighter ${ }^{12} \mathrm{C}$ will both break and react faster. However, similarly to the concentration data, isotopic trends obtained from laboratory scale production of abiotic hydrocarbons vary (McCollom, 2013). Furthermore, it is not uncommon to see patterns in natural samples which are somewhere between these two. Zhang et al. (2013) proposed that different trends could be related to thermal history. According to their study, cracking of earlier formed longer chained hydrocarbons with increasing temperature would produce a typical thermogenic pattern while the reversed carbon isotope trend could be preserved in decreasing temperature. Kinnaman et al. (2007) found that large isotopic enrichment of both ${ }^{2} \mathrm{H}$ and ${ }^{13} \mathrm{C}$ in the substrate was associated with aerobic microbial $\mathrm{CH}_{4}$ oxidation. Thus the isotopic pattern could likely be changed by microbial processes. They also found that the fractionation clearly decreased with increasing chain length and/or when the substrate became limiting. This has important implications for deep continental subsurface environments which are characteristically substrate-limited. There, isotope fractionation by microbial processes is expected to diminish and may even be absent if the substrate is completely consumed.

\section{Other Co-existing Gases}

In addition to carbon containing gases, other co-existing gases such as noble gases and $\mathrm{N}_{2}$ can be used to trace the origin of $\mathrm{CH}_{4}$. A major drawback related to using co-existing gases is the possible decoupling of these gases and $\mathrm{CH}_{4}$.
As they are inert, noble gases are very useful in tracing gas migration. For example they may be used to distinguish between mantle and crustal sources of gases (Kipfer et al., 2002; Prinzhofer, 2013; Sano and Fischer, 2013). Noble gases have also been used to determine residence times of deep groundwaters within crystalline shields in Canada (Bottomley et al., 1990; Greene et al., 2008; Holland et al., 2013), Fennoscandia (Kietäväinen et al., 2014; Trinchero et al., 2014), and South Africa (Lippmann et al., 2003). These studies have revealed ancient fluids within these formations extending from several millions of years to over a billion years old. Even though the information on residence times obtained from noble gases is indirect, and often comes with high uncertainties, it can be potentially utilized in estimating timing and rates of $\mathrm{CH}_{4}$ production as well as isolation of the subsurface ecosystems. Examples of this method are included in the studies by Lin et al. (2006b) and Schlegel et al. (2011).

Isotopic composition of $\mathrm{N}_{2}$ in groundwaters of the Fennoscandian and Canadian shields was used by Sherwood Lollar et al. (1993a) to show that hydrocarbons were not related to shallow atmosphere derived fluids but originated from the crystalline basement. Attempts to separate between inorganic and organic sources of hydrocarbons may also benefit from determination of $\mathrm{N}_{2}$ isotopes, as ${ }^{15} \mathrm{~N}$ depleted values are suggested to be representative of organic origin (Sano et al., 1993; Zhu et al., 2000; Etiope et al., 2011). As $\mathrm{N}_{2}$ is the main constituent of air, atmospheric contamination during sampling or analysis is a real risk to be aware of.

\section{Radiocarbon}

Attempts have also been made to estimate the age of $\mathrm{CH}_{4}$ by using radiocarbon $\left({ }^{14} \mathrm{C}\right)$ dating. One such study was performed by Slater et al. (2006) among the deep continental bedrock sites in Witwatersrand Basin, South Africa. By comparing the ${ }^{14} \mathrm{C}$ isotopic composition of DIC and $\mathrm{CH}_{4}$ they concluded that the majority of the $\mathrm{CH}_{4}$ was produced in the distant past. Potential problems of this method include the contamination of typically $\mathrm{CO}_{2}$-undersaturated groundwater samples by atmospheric $\mathrm{CO}_{2}$, and recent formation of $\mathrm{CH}_{4}$ from ancient (or ${ }^{~}{ }^{14} \mathrm{C}$ dead") carbon source. In the former case, the apparent age of DIC may be underestimated, while in the latter case $\mathrm{CH}_{4}$ from ongoing processes could be interpreted as ancient. Nevertheless, ${ }^{14} \mathrm{C}$ determination could help with tracing the carbon source. For example, Stotler et al. (2010) found that the carbon source for $\mathrm{CH}_{4}$ in the Lupin mine in Canada was older than could be dated with ${ }^{14} \mathrm{C}$, i.e., more than $50 \mathrm{ka}$.

\section{Clumped Isotopes}

Recently, clumped isotope methods have also been developed which are capable of determining the isotopologues of $\mathrm{CH}_{4}$ molecules (Stolper et al., 2014; Wang et al., 2015). Potential applications of the method include determination of $\mathrm{CH}_{4}$ formation temperature $\left(\mathrm{CH}_{4}\right.$ thermometry), and detection of kinetic isotope fractionation, both of which might be used in separating biotic from abiotic $\mathrm{CH}_{4}$ (Stolper et al., 2014; Wang et al., 2015). More applications are expected when this method comes more widely attainable. 


\section{Microbes Involved in Methane Cycling in the Fennoscandian Shield and Other Deep Precambrian Continental Subsurface Environments}

\section{Outokumpu Deep Drill Hole}

Formation waters at the $2.5 \mathrm{~km}$ deep scientific drill hole in Outokumpu, eastern Finland are characterized by high salinity and abundant dissolved gas phase of which $\mathrm{CH}_{4}$ covers up to 80 vol-\% (Table 1). The bedrock in Outokumpu is composed of several geochemically different rock types. These include serpentinites which have gained a lot of attention recently in the studies of abiotic $\mathrm{CH}_{4}$, along with black schists which contain abundant C. To date, Outokumpu Deep Drill Hole is the deepest site within the Fennoscandian Shield where $\mathrm{CH}_{4}$ cycling microbes have been studied.

Marker genes for methanogenesis, $m c r$ A were detected throughout the drill hole water column to $1500 \mathrm{~m}$ depth with a quantitative PCR assay (Itävaara et al., 2011a). Thus the existence of methanogens in Outokumpu could be verified, even though the copy numbers in a $\mathrm{ml}$ of drill hole water were essentially low (around $1 \times 10^{2}$ copies $\mathrm{mL}^{-1}$ ). The overall ratio of methanogens vs. total number of bacteria was less than $1 \%$. Cloning of the methanogenesis marker gene from the drill hole water suggested that at depths of $900 \mathrm{~m}$ or shallower, aceticlastic Methanosarcina were present in the methanogenic communities. Methylotrophic Methanolobus -type of OTUs were detected by cloning and high-throughput sequencing methods from 1.1, 1.3, and $1.5 \mathrm{~km}$ depths (Nyyssönen et al., 2014; Purkamo et al., 2015). Lithology of the latter depths is dominated by serpentinites and black schists and statistically corresponds with the detection of mcrA genes of Methanolobus (Västi, 2011; Purkamo et al., 2015). Majority of the mcrA clones and pyrosequenced archaeal 16S rRNA OTUs from the deepest part of the drill hole $(1.9 \mathrm{~km}$ depth and below) were related to Methanobacterium -associated methanogens (Nyyssönen et al., 2014; Purkamo et al., 2015). Further proof for autotrophic methanogenesis in the deepest part of the drill hole was received from the metagenome of the sample from $2.3 \mathrm{~km}$ depth, in which genes involved in autotrophic methanogenesis were detected (Nyyssönen et al., 2014).

The bedrock fracture zones represent different microbial community as the drill hole at the same depth. When observing the intrinsic archaeal communities in bedrock fracture zones at different depths of Outokumpu bedrock, Purkamo et al. (2013) confirmed that hydrogenotrophic Methanobacteriaceae were dominating the archaeal community in the fracture zones at 500 and $2260 \mathrm{~m}$ levels. In addition, a small part of the archaeal community at these depths contained aceticlastic Methanosarcina. The results were based both on DNA and RNA, thus it can be presumed that these methanogens were active in these fractures. Despite of confirmed methanogenic activity in Outokumpu, $\mathrm{CH}_{4}$ is ${ }^{13} \mathrm{C}$ rich (Table 1). Thus, it cannot be classified as microbial within traditional limits for isotopic composition of biological $\mathrm{CH}_{4}$.

In addition to methanogens, the existence and activity of methanotrophic microbes in Outokumpu groundwater is established. By cloning of the marker gene for particulate methane monooxygenase enzyme ( $p m o \mathrm{~A}$ ), Purkamo et al. (2015) demonstrated that aerobic methanogens are part of the microbial communities at 600,900 , and $1500 \mathrm{~m}$ depths of the drill hole water column. All clones in this study were affiliated with a $\gamma$-proteobacterial Methylomonas methanica. Rajala et al. (2015) verified that methanotrophs at $500 \mathrm{~m}$ fracture zone could be rapidly activated with $\mathrm{CH}_{4}$, methanol and sulfate. No ANMEassociated $m c r A$ was found in these studies, suggesting either that an another type of anaerobic methane oxidation pathway than reverse methanogenesis could be more likely in Outokumpu, or aerobic oxidation of $\mathrm{CH}_{4}$ by bacteria is more likely in Outokumpu, or the mcrA primers used in these studies do not detect ANME-type of morA.

\section{Olkiluoto}

Olkiluoto in southwestern Finland is the future repository site for nuclear waste. The bedrock in Olkiluoto is comprised of migmatitic mica gneisses. Similarly to Outokumpu, the deep groundwater in Olkiluoto is anaerobic and saline (Nyyssönen et al., 2012). Concentration of $\mathrm{CH}_{4}$ is among the highest observed today from any Precambrian crystalline bedrock site (Table 1). The microbial communities in different parts and depths of Olkiluoto site have been under observation for several years. Traditional most probable number (MPN) cultivation methods have described methylotrophs in shallow depths and methanogens to the depth of at least $450 \mathrm{~m}$. Methanogens were present in small numbers, $1 \times 10^{0}$ from $1 \times 10^{1}$ cells $\mathrm{mL}^{-1}$ (Pedersen et al., 2008). Using molecular biological methods, Nyyssönen et al. (2012) reported that the majority of $m c r A$ clones acquired from shallow $(<400 \mathrm{~m})$ depths of different drill holes in Olkiluoto fell within a metabolically diverse group of methanogens, namely Methanosarcinales. In addition, Methanoregula boonei of the Methanomicrobiales mcrA sequences were detected, while hydrogenotrophic Methanobacteriales -type of mcrA were found below $500 \mathrm{~m}$ depth. The $m c r A$ copy numbers detected with qPCR varied from less than 200 copies to below detection limit $\mathrm{mL}^{-1}$ of groundwater. Apparently the archaeal communities are diverse in Olkiluoto but methanogenic archaea represent only a minority ranging from 10 to $0.4 \%$ of the archaeal community (Bomberg et al., 2014).

Nyyssönen et al. (2012) detected mcrA of putative anaerobic methane oxidizers, i.e., ANME archaea in a single sample from $350 \mathrm{~m}$ depth. In addition, this sample had the highest number of $m c r$ A gene copies, 660 copies $\mathrm{mL}^{-1}$. This depth is considered to be within the sulfate-methane transition zone in the Olkiluoto bedrock. A flow cell cultivation study provided further evidence of existence of ANME archaea in Olkiluoto (Pedersen, 2013). In addition, it was shown that the active archaeal communities at depths of from 300 to $800 \mathrm{~m}$ in Olkiluoto consisted of, among others, ANME-2D archaea (Bomberg et al., 2015). These findings of ANME archaea are further proof for the hypothesis of Pedersen et al. (2008) that the anaerobic oxidation of methane is an active microbial process in the Olkiluoto bedrock. 


\section{Äspö, Laxemar, and Forsmark}

Another important Fennoscandian shield sites where deep biosphere studies have been conducted are in Sweden. Probably the most famous is the Äspö Hard Rock Laboratory (HRL) that has been running since 1995, in addition to Laxemar-Simpevarp and Forsmark which have been suggested for the final repository sites for nuclear waste. Äspö HRL extends to $450 \mathrm{~m}$ depth in porphyritic granite/granodiorite bedrock, whereas Forsmark lithology comprises of granites and Laxemar-Simpevarp granites and quartz monzodiorite (Table 1). Both salinity and $\mathrm{CH}_{4}$ concentrations are much lower in all Swedish sites compared to Olkiluoto and Outokumpu (Table 1). To our knowledge, no information on isotopic composition of $\mathrm{CH}_{4}$ detected at the Swedish sites exists. Pedersen (1997) demonstrated that methylotrophic and aceticlastic methanogens dominated at shallower depths above $200 \mathrm{~m}$, where more organic carbon was available. In the deeper depths where organic carbon content was lower, autotrophic methanogens were more frequent. Kotelnikova et al. (1998) isolated an autotrophic methanogen from Äspö groundwater, Methanobacterium subterraneum. Hallbeck and Pedersen (2008a, 2012) found low numbers of methanogens based on the most probable number method from samples of all these three sites.

In addition to methanogens, methanotrophs have also been detected from deep bedrock of Äspö and Forsmark. Clone libraries of methanotrophy marker gene pmoA were dominated by Methylomonas and Methylocystis (Chi Fru, 2008). Methylomonas and Methylobacter dominated enrichment cultures from Äspö groundwater from below $400 \mathrm{~m}$ depth (Kalyuzhnaya et al., 1999). To conclude, methanotrophs are detected approximately at the same depths in all Fennoscandian Shield sites, mainly above $1 \mathrm{~km}$.

\section{Witwatersrand and Other Deep Precambrian Continental Subsurface Study Sites}

Another widely studied deep biosphere is located in the Witwatersand Basin in South Africa. The geological formation is composed of quartzite and shale with overlying basaltic and andesitic rocks, on top of the schist basement (Ward et al., 2004). Several sites in the Witwatersrand Basin have been studied and methanogenic as well as ANME archaea have been detected with cloning of 16s rRNA gene (Takai et al., 2001; Ward et al., 2004; Moser et al., 2005; Lin et al., 2005a, 2006a,b; Gihring et al., 2006). $\mathrm{CH}_{4}$ is a common constituent of the gas phase in all of these sites (Table 1). A wide range of isotopic compositions have been reported, including ${ }^{13} \mathrm{C}$ poor $\mathrm{CH}_{4}$. In the Beatrix mine methanogens have been detected from 718 to $1390 \mathrm{~m}$ depths (Ward et al., 2004). At the depth of $866 \mathrm{mbls}$ (BE16) Methanobacterium-type of clones were most abundant, while other detected methanogens affiliated with aceticlastic Methanosarcina and Methanosaeta (Lin et al., 2006a). The archaeal communities in the Evander mine at the depth of $1950 \mathrm{~m}$ (EV818) were composed of Methanosarcina, Methanosaeta in addition to Methanolobus (Ward et al., 2004; Gihring et al., 2006). Methanobacterium-type hydrogenotrophic methanogens were found typically in deeper samples in the Witwatersrand Basin, such as from the Mponeng and Driefontein mines from over $2.7 \mathrm{~km}$ depth (Moser et al., 2005; Gihring et al., 2006). In the Driefontein mine site D8A, at more than $3 \mathrm{~km}$ depth the archaeal community comprised about $10 \%$ of the total microbial community and was dominated by Methanobacterium (Moser et al., 2005). Methanobacterium affiliating 16s rRNA sequences were detected also from the Mponeng mine at $2825 \mathrm{~m}$ depth (Lin et al., 2005a). Aceticlastic methanogens were typically found in depths shallower than $2 \mathrm{~km}$ at the Witwatersrand Basin whereas hydrogenotrophic methanogens such as Methanobacterium dominated at deeper depths. Gihring et al. (2006) suggested that high temperature and reducing conditions were the determining geochemical factors for the occurrence of Methanobacteriales in the fractures of the Witwatersrand Basin.

Anaerobic oxidation of methane in the deep subsurface in the Witwatersrand Basin is plausible, while archaeal 16s rRNA clones similar to methanotrophic ANME-1 archaea in Driefontein dolomitic aquifer and the Evander mine sites have been detected (Gihring et al., 2006).

Although life in the deep biosphere has been characterized in several sites as discussed above, there are some studies from deep continental bedrock sites where methanogens and methanotrophs could not be detected. These include the subsurface groundwaters from Palmottu, Kivetty, Romuvaara, and Hästholmen areas in the Fennoscandian Shield (Haveman et al., 1999; Haveman and Pedersen, 2002). Methanogenic archaea have not been detected from Kloof mine in the Witwatersrand Basin (Takai et al., 2001; Ward et al., 2004; Kieft et al., 2005). Neither did Onstott et al. (2009) detect any archaea from the Canadian Shield site in the Lupin mine. These results might indicate either real absence of methane cycling microbes at the sites or could be due to extremely low numbers of cells and/or inadequate sensitivity of analytical methods or because acquiring representative samples at field conditions is often challenging.

\section{Conclusions and Future Prospects}

The possibility of abiotic $\mathrm{CH}_{4}$ synthesis at low temperatures, together with findings of methanogenic microbes indicates that the formation of $\mathrm{CH}_{4}$ is an on-going process in deep Precambrian continental bedrock. In addition, the detection of aerobic, and recently also anaerobic methanotrophs deep within crystalline bedrock provide ecological evidence of microbial contribution to $\mathrm{CH}_{4}$ consumption in these environments. So far, the identified carbon sources of microbes range from inorganic $\mathrm{CO}_{2}$ to $\mathrm{CH}_{4}$ and other small organic carbon molecules, but there are intriguing hypotheses on microbial utilization of refractory organic carbon of minerals. Thus, the participation of heterotrophic microbes in carbon cycling in deep crystalline bedrock should not be dismissed.

As deep continental crystalline bedrock environments are commonly carbon-deprived, the traditional isotopic separation between biologically produced and abiotically produced $\mathrm{CH}_{4}$ can be difficult. When carbon sources are limited, the small amount of carbon available will be utilized without the preference for lighter isotope that is considered to happen in "normal" (surface) circumstances with abundant organic carbon. In addition, 
microbial activities, such as syntrophy or competition, especially in substrate-limited environments, can result to similar isotopic composition of $\mathrm{CH}_{4}$ produced in abiogenic reactions. Thus, further studies are needed especially considering the effect of syntrophy or competitiveness of microbial species, substrate availability and reaction rates on the isotopic composition of $\mathrm{CH}_{4}$. Furthermore, more studies on different forms of inorganic carbon (including minerals) available for both abiotic and biological organic synthesis will be advantageous.

Metabolically diverse methanoges were found at shallower depths while hydrogenotrophic methanogenesis appeared to be more common at greater depths throughout the sites. However, transition between the zones is not sharp and the depth varies among the sites. Considering the evolution of methanogenesis, the hydrogenotrophic pathway may be as old as life itself on Earth, while the capability to use acetate is considered to have evolved more recently during the Cambrian period (Costa and Leigh, 2014 and references within). As the oldest bedrock fluids are dated to be Precambrian (over 1 billion years old; Holland et al., 2013) it will be interesting to see if there are any methanogenic communities in these isolated fracture fluids, and will the hydrogenotrophic pathway dominate in these communities, as the hypothesis of the methanogenesis evolution implies. Similarly, further studies on depth dependence and the extent of isolation of different methanogens can shed light on the evolution of deep bedrock biosphere as well as $\mathrm{CH}_{4}$ cycling.

Growing industrial interest in utilizing deep rock formations as a natural resource such as mining of valuable metals or extracting shale gas, as storage for $\mathrm{CO}_{2}$, hydrocarbons or other fuels, as a part of infrastructure such as traffic tunnels, and production of geothermal heat and/or energy has increased the need for understanding the origin, source and cycling of $\mathrm{CH}_{4}$ in these environments. The natural state of the bedrock will be disturbed during these activities and release, production, and consumption of $\mathrm{CH}_{4}$ can affect industrial operations. $\mathrm{CH}_{4}$ may enhance biological activity by providing energy and carbon for microbial communities. In turn, this may increase the

\section{References}

Ahonen, L., Kaija, J., Paananen, M., Hakkarainen, V., and Ruskeeniemi, T. (2004). Palmottu Natural Analogue: A Summary of the Studies. Geological Survey of Finland, Nuclear Waste Disposal Research, Report YST-121. Available online at: http://tupa.gtk.fi/julkaisu/ydinjate/yst_121.pdf

Anttila, P., Ahokas, H., Front, K., Heikkinen, E., Hinkkanen, H., Johansson, E., et al. (1999). Final Disposal of Spent Nuclear Fuel in Finnish Bedrock - Kivetty Site Report. Posiva report 99-09, Posiva Oy, Olkiluoto. Available online at: http://www.posiva.fi/files/2691/POSIVA-99-09_web.pdf

Arthur, M. A., and Cole, D. R. (2014). Unconventional hydrocarbon resources: prospects and problems. Elements 10, 257-264. doi: 10.2113/gselements.10.4.257

Beal, E. J., House, C. H., and Orphan, V. J. (2009). Manganese- and iron-dependent marine methane oxidation. Science 325, 184-187. doi: 10.1126/science.11 69984

Bomberg, M., Nyyssönen, M., Nousiainen, A., Hultman, J., Paulin, L., Auvinen, P., et al. (2014). Evaluation of molecular techniques in characterization of deep terrestrial biosphere. Open J. Ecol. 4, 468-487. doi: 10.4236/oje.2014. 48040 concentrations of reactive compounds such as hydrogen and sulfide, especially in the presence of $\mathrm{SO}_{4}$, and change $\mathrm{pH}$ of the system thus increasing the corrosion risk. As a gaseous component, $\mathrm{CH}_{4}$ can also be important in mobilization of radiocarbon.

In order to understand $\mathrm{CH}_{4}$ cycling at depths, and the role of microorganisms within it, it is important to study the environmental conditions such as reduction-oxidation potential, isolation, and availability of substrates of the particular site together with microbiology. Geochemical methods may help to identify biotic from abiotic sources of $\mathrm{CH}_{4}$. Yet, no common characteristics in terms of $\mathrm{pH}, \mathrm{T}$, depth, lithology, abundance, and isotopic composition of $\mathrm{CH}_{4}$ could have been determined which would serve as diagnostic tools for estimating importance of microbial contribution in $\mathrm{CH}_{4}$ cycle in these environments. However, potential of new findings exists in all continental regions as to date very few sites have been studied at great detail or even superficially. For example, such studies would be beneficial in some Canadian Shield sites where extensive geochemical data on $\mathrm{CH}_{4}$ is available and world's oldest isolated bedrock fluids have been identified. In Sweden, on the other hand, more detailed geochemical characterization, including isotopic analyses could be helpful. In addition, development of new geochemical and microbiological methods, such as clumped isotopes and high-throughput sequencing can open new opportunities also in this field.

\section{Acknowledgments}

RK would like to thank Dr. Lasse Ahonen for commenting the manuscript and the Finnish Research Program on Nuclear Waste Management (grants SALAMI and RENGAS) for funding. LP would like to acknowledge M.Sc Elina Sohlberg for valuable discussions and criticism when compiling this review and Kone Foundation for financial support. Dr. Verity Flett is thanked for critical language revision. Reviewers are thanked for their constructive comments on the manuscript.

Bomberg, M., Nyyssönen, M., Pitkänen, P., Lehtinen, A., and Itävaara, M. (2015). Active microbial sulphate-methane interphase in deep bedrock fracture fluids in Olkiluoto, Finland. BioMed Res. Int. 979530. (in press).

Borgonie, G., García-Moyano, A., Litthauer, D., Bert, W., Bester, A., van Heerden, E., et al. (2011). Nematoda from the terrestrial deep subsurface of South Africa. Nature 474, 79-82. doi: 10.1038/nature09974

Borrel, G., O’Toole, P. W., Harris, H. M., Peyret, P., Brugere, J. F., and Gribaldo, S. (2013). Phylogenomic data support a seventh order of Methylotrophic methanogens and provide insights into the evolution of Methanogenesis. Genome Biol. Evol. 5, 1769-1780. doi: 10.1093/gbe/evt128

Bottomley, D. J., Gascoyne, M., and Kamineni, D. C. (1990). The geochemistry, age, and origin of groundwater in a mafic pluton, East Bull Lake, Ontario, Canada. Geochim. Cosmochim. Acta 54, 933-1008. doi: 10.1016/0016-7037(90) 90433-L

Bowman, J. (2006). The methanotrophs-the families Methylococcaceae and Methylocystaceae. Prokaryotes 5, 266-289. doi: 10.1007/0-387-30745-1_15

Bradley, A. S., Hayes, J. M., and Summons, R. E. (2009). Extraordinary ${ }^{13} \mathrm{C}$ enrichment of diether lipids at the Lost City Hydrothermal Field indicates a carbon-limited ecosystem. Geochim. Cosmochim. Acta 73, 102-118. doi: 10.1016/j.gca.2008.10.005 
Bradley, A. S., and Summons, R. E. (2010). Multiple origins of methane at the Lost City Hydrothermal Field. Earth Planet. Sci. Lett. 297, 34-41. doi: 10.1016/j.epsl.2010.05.034

Brazelton, W. J., Nelson, B., and Schrenk, M. O. (2012). Metagenomic evidence for $\mathrm{H}_{2}$ oxidation and $\mathrm{H}_{2}$ production by serpentinite-hosted subsurface microbial communities. Front. Microb. 2:268. doi: 10.3389/fmicb.2011.00268

Buseck, P. R., and Beyssac, O. (2014). From organic matter to graphite: graphitization. Elements 10, 421-426. doi: 10.2113/gselements.10.6.421

Caldwell, S. L., Laidler, J. R., Brewer, E. A., Eberly, J. O., Sandborgh, S. C., and Colwell, F. S. (2008). Anaerobic oxidation of methane: mechanisms, bioenergetics, and the ecology of associated microorganisms. Environ. Sci. Technol. 42, 6791-6799. doi: 10.1021/es800120b

Caporaso, J. G., Kuczynski, J., Stombaugh, J., Bittinger, K., Bushman, F. D., Costello, E. K., et al. (2010). QIIME allows analysis of highthroughput community sequencing data. Nat. Methods 7, 335-336. doi: 10.1038/nmeth.f.303

Chapelle, F. M., O’Neill, K., Bradley, P. M., Methé, B. A., Ciufo, S., and A., Knobel, L. L., et al. (2002). A hydrogen-based subsurface microbial community dominated by methanogens. Nature 415, 312-315. doi: 10.1038/415312a

Chi Fru, E. (2008). Constraints in the colonization of natural and engineered subterranean igneous rock aquifers by aerobic methane-oxidizing bacteria inferred by culture analysis. Geobiology 6, 365-375. doi: 10.1111/j.14724669.2008.00164.x

Chin, K., Lueders, T., Friedrich, M., Klose, M., and Conrad, R. (2004). Archaeal community structure and pathway of methane formation on rice roots. Microb. Ecol. 47, 59-67. doi: 10.1007/s00248-003-2014-7

Chistoserdova, L., Kalyuzhnaya, M. G., and Lidstrom, M. E. (2009). The expanding world of methylotrophic metabolism. Annu. Rev. Microbiol. 63, 477-499. doi: 10.1146/annurev.micro.091208.073600

Chivian, D., Brodie, E. L., Alm, E. J., Culley, D. E., Dehal, P. S., DeSantis, T. Z., et al. (2008). Environmental genomics reveals a single-species ecosystem deep within Earth. Science 10, 275-278. doi: 10.1126/science.1155495

Clark, I., and Fritz, P. (1997). Environmental Isotopes in Hydrogeology. Boca Raton, FL: Lewis Publishers.

Coleman, D. D., Risatti, J. B., and Schoell, M. (1981). Fractionation of carbon and hydrogen isotopes by methane-oxidizing bacteria. Geochim. Cosmochim. Acta 45, 1033-1037. doi: 10.1016/0016-7037(81)90129-0

Costa, K. C., and Leigh, J. A. (2014). Metabolic versatility in methanogens. Curr. Opin. Biotechnol. 29, 70-75. doi: 10.1016/j.copbio.2014.02.012

Dhillon, A., Lever, M., Lloyd, K. G., Albert, D. B., Sogin, M. L., and Teske, A. (2005). Methanogen diversity evidenced by molecular characterization of methyl coenzyme $\mathrm{M}$ reductase A (mcrA) genes in hydrothermal sediments of the Guaymas Basin. Appl. Environ. Microbiol. 71, 4592-4601. doi: 10.1128/AEM.71.8.4592-4601.2005

Drake, H., and Tullborg, E.-L. (2009). Paleohydrogeological events recorded by stable isotopes, fluid inclusions and trace elements in fracture minerals in crystalline rock, Simpevarp area, SE Sweden. Appl. Geochem. 24, 715-732. doi: 10.1016/j.apgeochem.2008.12.026

Ekendahl, S., O'Neill, A. H., Thomsson, E., and Pedersen, K. (2003). Characterization of yeasts isolated from deep igneous rock aquifers of the Fennoscandian shield. Microb. Ecol. 46, 416-428. doi: 10.1007/s00248-0032008-5

Etiope, G., Baciu, C. L., and Schoell, M. (2011). Extreme methane deuterium, nitrogen and helium enrichment in natural gas from the Homorod seep (Romania). Chem. Geol. 280, 89-96. doi: 10.1016/j.chemgeo.2010.10.019

Etiope, G., and Ionescu, A. (2014). Low-temperature catalytic CO2 hydrogenation with geologic quantities of ruthenium: a possible abiotic $\mathrm{CH} 4$ source in chromitite-rich serpentinized rocks. Geofluids. doi: 10.1111/gfl.12106. [Epub ahead of print].

Etiope, G., and Martinelli, G. (2002). Migration of carrier and trace gases in the geosphere: an overview. Phys. Earth Planet. Inter. 129, 185-204. doi: 10.1016/S0031-9201(01)00292-8

Etiope, G., and Schoell, M. (2014). Abiotic gas: atypical, but not rare. Elements 10, 291-296. doi: 10.2113/gselements.10.4.291

Etiope, G., and Sherwood Lollar, B. (2013). Abiotic methane on Earth. Rev. Geophys. 51, 276-299. doi: 10.1002/rog.20011

Ettwig, K. F., Butler, M. K., Le Paslier, D., Pelletier, E., Mangenot, S., Kuypers, M. M., et al. (2010). Nitrite-driven anaerobic methane oxidation by oxygenic bacteria. Nature 464, 543-548. doi: 10.1038/nature08883
Ferry, J. G. (2010). The chemical biology of methanogenesis. Planet. Space Sci. 58, 1775-1783. doi: 10.1016/j.pss.2010.08.014

Ferry, J. G. (2011). Fundamentals of methanogenic pathways that are key to the biomethanation of complex biomass. Curr. Opin. Biotechnol. 22, 351-357. doi: 10.1016/j.copbio.2011.04.011

Frape, S. K., Blyth, A., Blomqvist, R., McNutt, R. H., and Gascoyne, M. (2003). Deep fluids in the continents: II. Crystalline rocks. Treatise Geochem. 5, 541-580. doi: 10.1016/B0-08-043751-6/05086-6

Fredrickson, J. K., and Balkwill, D. L. (2006). Geomicrobial processes and biodiversity in the deep terrestrial subsurface. Geomicrobiol. J. 23, 345-356. doi: 10.1080/01490450600875571

Fredrickson, J. K., McKinley, J. P., Bjornstad, B. N., Ringelberg, D. B., White, D. C., Krumholz, L. R., et al. (1997). Pore-size constraints on the activity and survival of subsurface bacteria in a late Cretaceous shale-sandstone sequence, northwestern New Mexico. Geomicrobiol. J. 14,183-202. doi: 10.1080/01490459709378043

Fredrickson, J. K., Zachara, J. M., Balkwill, D. L., Kennedy, D., Li, S. M., Kostandarithes, H. M., et al. (2004). Geomicrobiology of high-level nuclear waste-contaminated vadose sediments at the hanford site, washington state. Appl. Environ. Microbiol. 70, 4230-4241. doi: 10.1128/AEM.70.7.42304241.2004

Fritz, P., Frape, S. K., and Miles, M. (1987). Methane in the crystalline rocks of the Canadian Shield. Geol. Assoc. Canada 33, 211-223. doi: 10.1016/00092541(88)90117-9

Galimov, E. M. (1988). Sources and mechanisms of formation of gaseous hydrocarbons in sedimentary rocks. Chem. Geol. 71, 77-95. doi: 10.1016/00092541(88)90107-6

Garcia, J., Patel, B. K., and Ollivier, B. (2000). Taxonomic, phylogenetic, and ecological diversity of methanogenic archaea. Anaerobe 6, 205-226. doi: 10.1006/anae. 2000.0345

Gihring, T., Moser, D., Lin, L., Davidson, M., Onstott, T., Morgan, L., et al. (2006). The distribution of microbial taxa in the subsurface water of the Kalahari Shield, South Africa. Geomicrobiol. J. 23, 415-430. doi: 10.1080/014904506008 75696

Greene, S., Battye, N., Clark, I., Kotzer, T., and Bottomley, D. (2008). Canadian Shield brine from the Con Mine, Yellowknife, NT, Canada: Noble gas evidence for an evaporated Palaeozoic seawater origin mixed with glacial meltwater and Holocene recharge. Geochim. Cosmochim. Acta 72, 4008-4019. doi: 10.1016/j.gca.2008.05.058

Hallam, S. J., Putnam, N., Preston, C. M., Detter, J. C., Rokhsar, D., Richardson, P. M., et al. (2004). Reverse methanogenesis: testing the hypothesis with environmental genomics. Science 305, 1457-1462. doi: $10.1126 /$ science. 1100025

Hallbeck, L., and Pedersen, K. (2008a). Characterization of microbial processes in deep aquifers of the Fennoscandian Shield. Appl. Geochem. 23, 1796-1819. doi: 10.1016/j.apgeochem.2008.02.012

Hallbeck, L., and Pedersen, K. (2008b). Explorative Analyses of Microbes, Colloids, and Gases Together with Microbial Modeling: Site Description Model SDMSite Laxemar. SKB Report R-08-109, Swedish Nuclear Fuel and Waste Management Co., Stockholm. Available online at: http://www.iaea.org/inis/ collection/NCLCollectionStore/_Public/40/021/40021023.pdf

Hallbeck, L., and Pedersen, K. (2012). Culture-dependent comparison of microbial diversity in deep granitic groundwater from two sites considered for a Swedish final repository of spent nuclear fuel. FEMS Microbiol. Ecol. 81, 66-77. doi: 10.1111/j.1574-6941.2011.01281.x

Hanson, R. S., and Hanson, T. E. (1996). Methanotrophic bacteria. Microbiol. Rev. 60, 439-471.

Haritash, A. K., and Kaushik, C. P. (2009). Biodegradation aspects of polycyclic aromatic hydrocarbons (PAHs): a review. J. Hazard. Mater. 169, 1-15. doi: 10.1016/j.jhazmat.2009.03.137

Harms, H., Schlosser, D., and Wick, L. Y. (2011). Untapped potential: expoiting fungi in bioremediation of hazardous chemicals. Nat. Rev. Microbiol. 9, 177-192. doi: 10.1038/nrmicro2519

Haroon, M. F., Hu, S., Shi, Y., Imelfort, M., Keller, J., Hugenholtz, P., et al. (2013). Anaerobic oxidation of methane coupled to nitrate reduction in a novel archaeal lineage. Nature 500, 567-570. doi: 10.1038/nature12375

Haveman, S. A., and Pedersen, K. (2002). Distribution of culturable microorganisms in Fennoscandian Shield groundwater. FEMS Microbiol. Ecol. 39, 129-137. doi: 10.1111/j.1574-6941.2002.tb00914.x 
Haveman, S. A., Pedersen, K., and Ruotsalainen, P. (1999). Distribution and metabolic diversity of microorganisms in deep igneous rock aquifers of Finland. Geomicrobiol. J. 16, 277-294. doi: 10.1080/014904599270541

Hirayama, H., Suzuki, Y., Abe, M., Miyazaki, M., Makita, H., Inagaki, F., et al. (2011). Methylothermus subterraneus sp. nov., a moderately thermophilic methanotroph isolated from a terrestrial subsurface hot aquifer. Int. J. Syst. Evol. Microbiol. 61, 2646-2653. doi: 10.1099/ijs.0.028092-0

Hoefs, J. (2004). Stable Isotope Geochemistry. Berlin; Heidelberg: Springer-Verlag. doi: 10.1007/978-3-662-05406-2

Holland, G., Sherwood Lollar, B., Li, L., Lacrampe-Couloume, G., Slater, G. F., and Ballentine, C. J. (2013). Deep fracture fluids isolated in the crust since the Precambrian era. Nature 497, 357-360. doi: 10.1038/nature12127

Horita, J., and Berndt, M. E. (1999). Abiogenic methane formation and isotopic fractionation under hydrothermal conditions. Science 285, 1055-1057. doi: $10.1126 /$ science.285.5430.1055

Itävaara, M., Nyyssönen, M., Bomberg, M., Kapanen, A., Nousiainen, A., Ahonen, L., et al. (2011a). Microbiological sampling and analysis of the Outokumpu Deep Drill Hole biosphere in 2007-2009. Geol. Surv. Finland 51, 199-206.

Itävaara, M., Nyyssönen, M., Kapanen, A., Nousiainen, A., Ahonen, L., and Kukkonen, I. (2011b). Characterization of bacterial diversity to a depth of $1500 \mathrm{~m}$ in the Outokumpu deep borehole, Fennoscandian Shield. FEMS Microbiol. Ecol. 77, 295-309. doi: 10.1111/j.1574-6941.2011.01111.x

Jacquemin, M., Beuls, A., and Ruiz, P. (2010). Catalytic production of methane from $\mathrm{CO}_{2}$ and $\mathrm{H}_{2}$ at low temperature: insight on the reaction mechanism. Catal. Today 157, 462-366. doi: 10.1016/j.cattod.2010.06.016

Juottonen, H., Galand, P. E., and Yrjälä, K. (2006). Detection of methanogenic Archaea in peat: comparison of PCR primers targeting the mcrA gene. Res. Microbiol. 157, 914-921. doi: 10.1016/j.resmic.2006.08.006

Kaija, J., Blomqvist, R., Ahonen, L., and Hakkarainen, V. (1998). The Hydrogeochemical Database of Palmottu. The Palmottu Natural Analogue Project, Technical Report 98-08. Available online at: http://tupa.gtk.fi/raportti/ arkisto/y50_98_08.pdf

Kalyuzhnaya, M. G., Khmelenina, V. N., Kotelnikova, S., Holmquist, L., Pedersen, K., and Trotsenko, Y. A. (1999). Methylomonas scandinavica sp. nov., a new methanotrophic psychrotrophic bacterium isolated from deep igneous rock ground water of Sweden. Syst. Appl. Microbiol. 22, 565-572. doi: 10.1016/S07232020(99)80010-1

Karus, E. W., Nartikoyev, V. D., Bartashevich, O. V., Gigashvili, G. M., Ikorsky, S. V., Pavlolva, M. A., et al. (1987). "Gases and organic matter," in The Superdeep Well of the Kola Peninsula, ed Y. A. Kozlovsky (Berlin; Heidelberg: Springer-Verlag), 243-270.

Kelley, C. A., Poole, J. A., Tazaz, A. M., Chanton, J. P., and Bebout, B. M. (2012). Substrate limitation for methanogenesis in hypersaline environments. Astrobiology 12, 89-97. doi: 10.1089/ast.2011.0703

Kieft, T. L., McCuddy, S. M., Onstott, T. C., Davidson, M., Lin, L., Mislowack, B., et al. (2005). Geochemically generated, energy-rich substrates and indigenous microorganisms in deep, ancient groundwater. Geomicrobiol. J. 22, 325-335. doi: 10.1080/01490450500184876

Kietäväinen, R., Ahonen, L., Kukkonen, I. T., Hendriksson, N., Nyyssönen, M., and Itävaara, M. (2013). Characterisation and isotopic evolution of saline waters of the Outokumpu Deep Drill Hole, Finland-Implications for water origin and deep terrestrial biosphere. Appl. Geochem. 32, 37-51. doi: 10.1016/j.apgeochem.2012.10.013

Kietäväinen, R., Ahonen, L., Kukkonen, I. T., Niedermann, S., and Wiersberg, T. (2014). Noble gas residence times of saline waters within crystalline bedrock, Outokumpu Deep Drill Hole, Finland. Geochim. Cosmochim. Acta 145, 159-174. doi: 10.1016/j.gca.2014.09.012

Kimura, H., Nashimoto, H., Shimizu, M., Hattori, S., Yamada, K., Koba, K., et al. (2010). Microbial methane production in deep aquifer associated with the accretionary prism in Southwest Japan. ISME J. 4, 531-541. doi: 10.1038/ismej.2009.132

Kinnaman, F. S., Valentine, D. L., and Tyler, S. C. (2007). Carbon and hydrogen isotope fractionation associated with the aerobic microbial oxidation of methane, ethane, propane and butane. Geochim. Cosmochim. Acta 71, 271-283. doi: 10.1016/j.gca.2006.09.007

Kipfer, R., Aeschbach-Hertig, W., Peeters, F., and Stute, M. (2002). Noble gases in lakes and ground waters. Rev. Mineral. Geochem. 47, 615-700. doi: 10.2138/rmg.2002.47.14
Kita, I., Matsuo, S., and Wakita, H. (1982). $\mathrm{H}_{2}$ generation by reaction between $\mathrm{H}_{2} \mathrm{O}$ and crushed rock: an experimental study on $\mathrm{H}_{2}$ degassing from the active fault zone. J. Geophys. Res. 87, 10,789-10,795.

Knittel, K., and Boetius, A. (2009). Anaerobic oxidation of methane: progress with an unknown process. Annu. Rev. Microbiol. 63, 311-334. doi: 10.1146/annurev.micro.61.080706.093130

Knittel, K., Losekann, T., Boetius, A., Kort, R., and Amann, R. (2005). Diversity and distribution of methanotrophic archaea at cold seeps. Appl. Environ. Microbiol. 71, 467-479. doi: 10.1128/AEM.71.1.467-479.2005

Kotelnikova, S. (2002). Microbial production and oxidation of methane in deep subsurface. Earth-Sci. Rev. 58, 367-395. doi: 10.1016/S0012-8252(01) 00082-4

Kotelnikova, S., Macario, A. J., and Pedersen, K. (1998). Methanobacterium subterraneum sp. nov., a new alkaliphilic, eurythermic and halotolerant methanogen isolated from deep granitic groundwater. Int. J. Syst. Bacteriol. 48, 357-367. doi: 10.1099/00207713-48-2-357

Kotelnikova, S., and Pedersen, K. (1997). Evidence for methanogenic archaea and homoacetogenic bacteria in deep granitic rock aquifers. FEMS Microbiol. Rev. 20, 339-349. doi: 10.1111/j.1574-6976.1997.tb00319.x

Kotelnikova, S., and Pedersen, K. (1998). Distribution and activity of methanogens and homoacetogens in deep granitic aquifers at Äspö Hard Rock Laboratory, Sweden. FEMS Microbiol. Ecol. 26, 121-134. doi: 10.1016/S0168-6496(98) 00028-2

Kretschmer, K., Biastoch, A., Rupke, L., and Burwicz, E. (2015). Modeling the fate of methane hydrates under global warming. Global Biogeochem. Cycles 29, 610-625. doi: 10.1002/2014GB005011

Krüger, M., Meyerdierks, A., Glockner, F. O., Amann, R., Widdel, F., and Kube, M., et al. (2003). A conspicuous nickel protein in microbial mats that oxidize methane anaerobically. Nature 426, 878-881. doi: 10.1038/nature02207

Krumholz, L. R., McKinley, J. P., Ulrich, G. A., and Suflita, J. M. (1997). Confined subsurface microbial communities in Cretaceous rock. Nature 386, 64-66 doi: 10.1038/386064a0

Kyle, J. E., Eydal, H. S., Ferris, F. G., and Pedersen, K. (2008). Viruses in granitic groundwater from 69 to $450 \mathrm{~m}$ depth of the Äspö hard rock laboratory, Sweden. ISME J. 2, 571-574. doi: 10.1038/ismej.2008.18

Lang, S. Q., Früh-Green, G. L., Bernasconi, S. M., Lilley, M. D., Proskurowski, G., Méhay, S., et al. (2012). Microbial utilization of abiogenic carbon and hydrogen in a serpentinite-hosted system. Geochim. Cosmochim. Acta 92, 82-99. doi: 10.1016/j.gca.2012.06.006

Langille, M. G., Zaneveld, J., Caporaso, J. G., McDonald, D., Knights, D., Reyes, J. A., et al. (2013). Predictive functional profiling of microbial communities using 16S rRNA marker gene sequences. Nat. Biotechnol. 31, 814-821. doi: $10.1038 /$ nbt. 2676

Lazar, C. S., Dinasquet, J., L'Haridon, S., Pignet, P., and Toffin, L. (2011a). Distribution of anaerobic methane-oxidizing and sulfate-reducing communities in the G11 Nyegga pockmark, Norwegian Sea. A. Van Leeuw. 100, 639-653. doi: 10.1007/s10482-011-9620-z

Lazar, C. S., L'Haridon, S., Pignet, P., and Toffin, L. (2011b). Archaeal populations in hypersaline sediments underlying orange microbial mats in the Napoli mud volcano. Appl. Environ. Microbiol. 77, 3120-3131. doi: 10.1128/AEM.01296-10

Lever, M. A., Rouxel, O., Alt, J. C., Shimizu, N., Ono, S., Coggon, R. M., et al. (2013). Evidence for microbial carbon and sulfur cycling in deeply buried ridge flank basalt. Science 339, 1305-1308. doi: 10.1126/science.1229240

Lin, L., Hall, J., Lippmann-Pipke, J., Ward, J. A., Sherwood Lollar, B., DeFlaun, M., et al. (2005a). Radiolytic $\mathrm{H}_{2}$ in continental crust: nuclear power for deep subsurface microbial communities. Geochem. Geophys. Geosyst. 6, Q07003. doi: 10.1029/2004GC000907

Lin, L., Hall, J., Onstott, T., Gihring, T., Lollar, B. S., Boice, E., et al. (2006a). Planktonic microbial communities associated with fracture-derived groundwater in a deep gold mine of South Africa. Geomicrobiol. J. 23, 475-497. doi: 10.1080/01490450600875829

Lin, L.-H., Slater, G. F., Sherwood Lollar, B., Lacrampe-Couloume, G., and Onstott, T. C. (2005b). The yield and isotopic composition of radiolytic $\mathrm{H}_{2}$, a potential energy source for the deep subsurface biosphere. Geochim. Cosmochim. Acta 69, 893-903. doi: 10.1016/j.gca.2004.07.032

Lin, L.-H., Wang, P.-L., Rumble, D., Lippmann-Pipke, J., Boice, E., Pratt, L. M., et al. (2006b). Long-term sustainability of a high-energy, low-diversity crustal biome. Science 314, 479-482. doi: 10.1126/science.1127376 
Lippmann, J., Stute, M., Torgersen, T., Moser, D. P., and Hall, J. A., Lin, et al. (2003). Dating ultra-deep mine waters with noble gases and ${ }^{36} \mathrm{Cl}$, Witwatersrand Basin, South Africa. Geochim. Cosmochim. Acta 67, 4597-4619. doi: 10.1016/S0016-7037(03)00414-9

Liu, Y., and Whitman, W. B. (2008). Metabolic, phylogenetic, and ecological diversity of the methanogenic Archaea. Ann. N. Y. Acad. Sci. 1125, 171-189. doi: 10.1196/annals.1419.019

Luton, P. E., Wayne, J. M., Sharp, R. J., and Riley, P. W. (2002). The $m c r$ A gene as an alternative to $16 \mathrm{~S}$ rRNA in the phylogenetic analysis of methanogen populations in landfill. Microbiology 148, 3521-3530.

Luukkonen, A., Pitkänen, P., Ruotsalainen, P., Leino-Forsman, H., and Snellman, M. (1999). Hydrogeochemical Conditions at the Hästholmen site. Posiva report 99-26, Posiva Oy, Helsinki. Available online at: http://www.posiva.fi/files/2708/ POSIVA-99-26_web.pdf

Mayhew, L. E., Ellison, E. T., McCollom, T. M., Trainor, T. P., and Templeton, A. S. (2013). Hydrogen generation from low-temperature water-rock reactions. Nat. Geosci. 6, 478-484. doi: 10.1038/ngeo1825

McCollom, T. M. (2013). Laboratory simulations of abiotic hydrocarbon formation in Earth's deep subsurface. Rev. Mineral. Geochem. 75, 467-494. doi: 10.2138/rmg.2013.75.15

McCollom, T. M., and Bach, W. (2009). Thermodynamic constraints on hydrogen generation during serpentinization of ultramafic rocks. Geochim. Cosmochim. Acta 73, 856-875. doi: 10.1016/j.gca.2008.10.032

McCollom, T. M., Sherwood Lollar, B., Lacrampe-Couloume, G., and Seewald, J. S. (2010). The influence of carbon source on abiotic organic synthesis and carbon isotope fractionation under hydrothermal conditions. Geochim. Cosmochim. Acta 74, 2717-2740. doi: 10.1016/j.gca.2010.02.008

Meyerdierks, A., Kube, M., Lombardot, T., Knittel, K., Bauer, M., Glöckner, F. O., et al. (2005). Insight into the genomes of archaea mediating the anaerobic oxidation of methane. Environ. Microbiol. 7, 1937-1951. doi: 10.1111/j.14622920.2005.00844.x

Milkov, A. V. (2011). Worldwide distribution and significance of secondary microbial methane formed during petroleum biodegradation in conventional reservoirs. Org. Geochem. 42, 184-207. doi: 10.1016/j.orggeochem.2010. 12.003

Mills, C. T., Amano, Y., Slater, G. F., Dias, R. F., Iwatsuki, T., and Mandernack, K. W. (2010). Microbial carbon cycling in oligotrophic regional aquifers near the Tono Uranium Mine, Japan as inferred from $\delta 13 \mathrm{C}$ and $\triangle 14 \mathrm{C}$ values of in situ phospholipid fatty acids and carbon sources. Geochim. Cosmochim. Acta 74, 3785-3805. doi: 10.1016/j.gca.2010.03.016

Mills, H. J., Hodges, C., Wilson, K., MacDonald, I. R., and Sobecky, P. A. (2003). Microbial diversity in sediments associated with surface-breaching gas hydrate mounds in the Gulf of Mexico. FEMS Microbiol. Ecol. 46, 39-52. doi: 10.1016/S0168-6496(03)00191-0

Milucka, J., Ferdelman, T. G., Polerecky, L., Franzke, D., Wegener, G., Schmid, M., et al. (2012). Zero-valent sulphur is a key intermediate in marine methane oxidation. Nature 491, 541-546. doi: 10.1038/nature11656

Morelli, R. M., Bell, C. C., Creaser, R. A., and Simonetti, A. (2010). Constraints on the genesis of gold mineralization at the Homestake Gold Deposit, Black Hills, South Dakota from rhenium-osmium sulfide geochronology. Miner. Deposita. 45, 461-480. doi: 10.1007/s00126-010-0284-9

Moser, D. P., Gihring, T. M., Brockman, F. J., Fredrickson, J. K., Balkwill, D. L., Dollhopf, M. E., et al. (2005). Desulfotomaculum and Methanobacterium spp. dominate a 4- to 5-kilometer-deep fault. Appl. Environ. Microbiol. 71, 8773-8783. doi: 10.1128/AEM.71.12.8773-8783.2005

Moser, D. P., Onstott, T. C., Fredrickson, J. K., Brockman, F. J., Balkwill, D. L., Drake, G. R., et al. (2003). Temporal shifts in the geochemistry and microbial community structure of an ultradeep mine borehole following isolation. Geomicrobiol. J. 20, 517-548. doi: 10.1080/713851170

Nandi, R., and Sengupta, S. (1998). Microbial production of hydrogen: an overview. Crit. Rev. Microbiol. 24, 61-84. doi: 10.1080/10408419891294181

Nazaries, L., Murrell, J. C., Millard, P., Baggs, L., and Singh, B. K. (2013). Methane, microbes and models: fundamental understanding of the soil methane cycle for future predictions. Environ. Microbiol. 15, 2395-2417. doi: 10.1111/14622920.12149

Nealson, K. H., Inagaki, F., and Takai, K. (2005). Hydrogen-driven subsurface lithoautotrophic microbial ecosystems (SLiMEs): do they exist and why should we care? Trends Microbiol. 13, 405-410. doi: 10.1016/j.tim.2005.07.010
Neubeck, A., Than Duc, N., Bastviken, D., Crill, P., and Holm, N. G. (2011). Formation of $\mathrm{H}_{2}$ and $\mathrm{CH}_{4}$ by weathering of olivine at temperatures between 30 and $70^{\circ} \mathrm{C}$. Geochem. Trans. 12, 6. doi: 10.1186/1467-4866-12-6

Ni, Y., Ma, Q., Ellis, G. S., Dai, J., Katz, B., Zhang, S., et al. (2011). Fundamental studies on kinetic isotope effect (KIE) of hydrogen isotope fractionation in natural gas systems. Geochim. Cosmochim. Acta 75, 2696-2707. doi: 10.1016/j.gca.2011.02.016

Nurmi, P. A., Kukkonen, I. T., and and, Lahermo, P. W. (1988). Geochemistry and origin of saline groundwaters in the Fennoscandian Shield. Appl. Geochem. 3, 185-203. doi: 10.1016/0883-2927(88)90007-8

Nyyssönen, M., Bomberg, M., Kapanen, A., Nousiainen, A., Pitkänen, P., and Itävaara, M. (2012). Methanogenic and sulphate-reducing microbial communities in deep groundwater of crystalline rock fractures in Olkiluoto, Finland. Geomicrobiol. J. 29, 863-878. doi: 10.1080/01490451.2011.635759

Nyyssönen, M., Hultman, J., Ahonen, L., Kukkonen, I., Paulin, L., Laine, P., et al. (2014). Taxonomically and functionally diverse microbial communities in deep crystalline rocks of the Fennoscandian shield. ISME J. 8, 126-138. doi: 10.1038/ismej.2013.125

Onstott, T. C., Lin, L.-H., Davidson, M., Mislowack, B., Borcsik, M., Hall, J., et al. (2006). The origin and age of biogeochemical trends in deep fracture water of the Witwatersrand Basin, South Africa. Geomicrobiol. J. 23, 369-414. doi: $10.1080 / 01490450600875688$

Onstott, T. C., McGown, D. J., Bakermans, C., Ruskeeniemi, T., Ahonen, L., Telling, J., et al. (2009). Microbial communities in subpermafrost saline fracture water at the Lupin Au Mine, Nunavut, Canada. Microb. Ecol. 58, 786-807. doi: 10.1007/s00248-009-9553-5

Orphan, V. J., House, C. H., Hinrichs, K. U., McKeegan, K. D., and DeLong, E. F. (2001). Methane-consuming archaea revealed by directly coupled isotopic and phylogenetic analysis. Science 293, 484-487. doi: 10.1126/science.1061338

Orphan, V. J., House, C. H., Hinrichs, K. U., McKeegan, K. D., and DeLong, E. F. (2002). Multiple archaeal groups mediate methane oxidation in anoxic cold seep sediments. Proc. Natl. Acad. Sci. U.S.A. 99, 7663-7668. doi: 10.1073/pnas.072210299

Osburn, M. R., LaRowe, D. E., Momper, L. M., and Amend, J. P. (2014). Chemolithotrophy in the continental deep subsurface: Sanford Underground Research Facility (SURF), USA. Front. Microbiol. 5:610. doi: 10.3389/fmicb.2014.00610

Paul, K., Nonoh, J. O., Mikulski, L., and Brune, A. (2012). 'Methanoplasmatales,' Thermoplasmatales-related archaea in termite guts and other environments, are the seventh order of methanogens. Appl. Environ. Microbiol. 78, 8245-8253. doi: 10.1128/AEM.02193-12

Pedersen, K. (1996). Investigations of subterranean bacteria in deep crystalline bedrock and their importance for the disposal of nuclear waste. Can. J. Microbiol. 42, 382-391. doi: 10.1139/m96-054

Pedersen, K. (1997). Microbial life in deep granitic rock. FEMS Microbiol. Rev. 20, 399-414. doi: 10.1111/j.1574-6976.1997.tb00325.x

Pedersen, K. (2000). Exploration of deep intraterrestrial microbial life: current perspectives. FEMS Microbiol. Lett. 185, 9-16. doi: 10.1111/j.1574-6968.2000.tb09033.x

Pedersen, K. (2013). Metabolic activity of subterranean microbial communities in deep granitic groundwater supplemented with methane and $\mathrm{H}_{2}$. ISME J. 7, 839-849. doi: 10.1038/ismej.2012.144

Pedersen, K., Arlinger, J., Eriksson, S., Hallbeck, A., Hallbeck, L., and Johansson, J. (2008). Numbers, biomass and cultivable diversity of microbial populations relate to depth and borehole-specific conditions in groundwater from depths of 4-450 m in Olkiluoto, Finland. ISME J. 2, 760-775. doi: 10.1038/ismej.2008.43

Pedersen, K., and Ekendahl, S. (1990). Distribution and activity of bacteria in deep granitic groundwaters of Southeastern Sweden. Microb. Ecol. 20, 37-52. doi: $10.1007 / \mathrm{BF} 02543865$

Pedersen, K., and Haveman, S. (1999). Analysis of Diversity and Distribution of Microorganisms in Palmottu Groundwater and Evaluation of their Influence on Redox Potential and Uranium (VI) Reduction. The Palmottu Natural Analogue Project, Technical Report 99-14. Available online at: http://tupa.gtk.fi/raportti/ arkisto/y50_99_14.pdf

Petsch, S. T., Edwards, K., and Eglinton, T. I. (2005). Microbial transformations of organic matter in black shales and implications for global biogeochemical cycles. Palaeogeogr. Palaeoclimatol. Palaeoecol. 219, 157-170. doi: 10.1016/j.palaeo.2004.10.019 
Petsch, S. T., Eglinton, T. I., and Edwards, K. J. (2001). 14C-dead living biomass: evidence for microbial assimilation of ancient organic carbon during shale weathering. Science 292, 1127-1131. doi: 10.1126/science. 1058332

Pitkänen, P., Luukkonen, A., Ruotsalainen, P., Leino-Forsman, H., and Vuorinen, U. (1998). Geochemical Modelling of Groundwater Evolution and Residence Time at the Kivetty Site. Posiva report 98-07, Posiva Oy, Helsinki. Available online at: http://www.posiva.fi/files/2672/POSIVA-98-07_web.pdf

Pitkänen, P., and Partamies, S. (2007). Origin and Implications of Dissolved Gases in Groundwater at Olkiluoto. Posiva report 2007-04, Posiva Oy, Olkiluoto. Available online at: http://www.posiva.fi/files/341/Posiva2007-04web.pdf

Pitkänen, P., Snellman, M., Vuorinen, U., and Leino-Forsman, H. (1996). Geochemical Modelling Study on the Age and Evolution of the Groundwater at the Romuvaara Site. Posiva report 96-06, Posiva Oy, Helsinki. Available online at: http://www.posiva.fi/files/3458/Posiva-96-06.pdf

Prinzhofer, A. (2013). "Noble gas in oil and gas accumulations," in The Noble Gases as Geochemical Tracers, ed P. Burnard (Berlin; Heidelberg: Springer-Verlag), 225-247. doi: 10.1007/978-3-642-28836-4_9

Purkamo, L., Bomberg, M., Nyyssönen, M., Kukkonen, I., Ahonen, L., and Itävaara, M. (2015). Heterotrophic communities supplied by ancient organic carbon predominate in deep Fennoscandian bedrock fluids. Microb. Ecol. 69, 319-332. doi: 10.1007/s00248-014-0490-6

Purkamo, L., Bomberg, M., Nyyssönen, M., Kukkonen, I., Ahonen, L., Kietäväinen, R., et al. (2013). Dissecting the deep biosphere: retrieving authentic microbial communities from packer-isolated deep crystalline bedrock fracture zones. FEMS Microbiol. Ecol. 85, 324-337. doi: 10.1111/1574-6941.12126

Raghoebarsing, A. A., Pol, A., Van de Pas-Schoonen, K. T., Smolders, A. J., Ettwig, K. F., Rijpstra, W. I. C., et al. (2006). A microbial consortium couples anaerobic methane oxidation to denitrification. Nature 440, 918-921. doi: 10.1038 /nature04617

Rajala, P., Bomberg, M., Kietäväinen, R., Kukkonen, I., Ahonen, L., Nyyssönen, M., et al. (2015). Rapid reactivation of deep subsurface microbes in the presence of C-1 compounds. Microorganisms 3, 17-33. doi: 10.3390/microorganisms3010017

Rastogi, G., Osman, S., Kukkadapu, R., Engelhard, M., Vaishampayan, P. A., Andersen, G. L., et al. (2010). Microbial and mineralogical characterizations of soils collected from the deep biosphere of the Former Homestake Gold Mine, South Dakota. Microb. Ecol. 60, 539-550. doi: 10.1007/s00248-0109657-y

Reeves, E. P., Seewald, J. S., and Sylva, S. P. (2012). Hydrogen isotope exchange between $n$-alkanes and water under hydrothermal conditions. Geochim. Cosmochim. Acta 77, 582-599. doi: 10.1016/j.gca.2011.10.008

Rosewarne, C. P., Greenfield, P., Li, D., Tran-Dinh, N., Bradbury, M. I., Midgley, D. J., et al. (2013a). Draft genome sequence of Clostridium sp. Maddingley, Isolated from coal-seam gas formation water. Genome Announc. 1:e00081-12. doi: 10.1128/genomeA.00081-12

Rosewarne, C. P., Greenfield, P., Li, D., Tran-Dinh, N., Midgley, D. J., and Hendry, P. (2013b). Draft genome sequence of Methanobacterium sp. Maddingley, reconstructed from metagenomic sequencing of a methanogenic microbial consortium enriched from coal-seam gas formation water. Genome Announc. 1:e00082-12. doi:10.1128/genomeA.00082-12

Ruppel, C. (2011). Methane hydrates and contemporary climate change. Nat. Educ. Knowl. 3, 29. Available online at: http://www.nature.com/scitable/knowledge/ library/methane-hydrates-and-contemporary-climate-change- 24314790

Sahlstedt, E., Karhu, J. A., and Pitkänen, P. (2010). Indications for the past redox environments in deep groundwaters from the isotopic composition of carbon and oxygen in fracture calcite, Olkiluoto, SW Finland. Isot. Environ. Health Stud. 46, 370-391. doi: 10.1080/10256016.2010.505981

Sano, Y., and Fischer, T. (2013). "The analysis and interpretation of noble gases in modern hydrothermal systems," in The Noble Gases as Geochemical Tracers, ed P. Burnard (Berlin; Heidelberg: Springer-Verlag), 249-317. doi: 10.1007/978-3642-28836-4_10

Sano, Y., Urabe, A., and Wakita, H. (1993). Origin of hydrogen-nitrogen gas seeps, Oman. Appl. Geochem. 8, 1-8. doi: 10.1016/0883-2927(93)90053-J

Schidlowski, M. (2001). Carbon isotopes as biogeochemical recorders of life over 3.8 Ga of Earth history: evolution of a concept. Precambrian Res. 106, 117-134. doi: 10.1016/S0301-9268(00)00128-5

Schlegel, M. E., Zhou, Z., McIntosh, J. C., Ballentine, C. J., and Person, M. A. (2011). Constraining the timing of microbial methane generation in an organic-rich shale using noble gases, Illinois Basin, USA. Chem. Geol. 287, 27-40. doi: 10.1016/j.chemgeo.2011.04.019

Schloss, P. D., Westcott, S. L., Ryabin, T., Hall, J. R., Hartmann, M., Hollister, E. B., et al. (2009). Introducing mothur: open-source, platformindependent, community-supported software for describing and comparing microbial communities. Appl. Environ. Microbiol. 75, 7537-7541. doi: 10.1128/AEM.01541-09

Schoell, M. (1980). The hydrogen and carbon isotopic composition of methane from natural gases of various origins. Geochim. Cosmochim. Acta 44, 649-661. doi: 10.1016/0016-7037(80)90155-6

Schrenk, M. O., Brazelton, W. J., and Lang, S. Q. (2013). Serpentinization, carbon, and deep life. Rev. Mineral. Geochem. 75, 575-606. doi: 10.2138/rmg.2013.75.18

Sherwood Lollar, B., Frape, S. K., Fritz, P., Macko, S. A., Welhan, J. A., Blomqvist, R., et al. (1993a). Evidence for bacterially generated hydrocarbon gas in Canadian Shield and Fennoscandian Shield rocks. Geochim. Cosmochim. Acta 57, 5073-5085. doi: 10.1016/0016-7037(93)90609-Z

Sherwood Lollar, B., Frape, S. K., Weise, S. M., Fritz, P., Macko, S. A., and Welhan, J. A. (1993b). Abiogenic methanogenesis in crystalline rocks. Geochim. Cosmochim. Acta 57, 5087-5097. doi: 10.1016/0016-7037(93)90610-9

Sherwood Lollar, B., Lacrampe-Couloume, G., Slater, G. F., Ward, J., Moser, D. P., Gihring, T. M., et al. (2006). Unravelling abiogenic and biogenic sources of methane in the Earth's deep subsurface. Chem. Geol. 226, 328-339. doi: 10.1016/j.chemgeo.2005.09.027

Sherwood Lollar, B., Onstott, T. C., Lacrampe-Couloume, G., and Ballentine, C. J. (2014). The contribution of the Precambrian continental lithosphere to global $\mathrm{H}_{2}$ production. Nature 516, 379-382. doi: 10.1038/nature14017

Sherwood Lollar, B., Westgate, T. D., Ward, J. A., Slater, G. F., and LacrampeCouloume, G. (2002). Abiogenic formation of alkanes in the Earth's crust as a minor source for global hydrocarbon reservoirs. Nature 416, 522-524. doi: $10.1038 / 416522 \mathrm{a}$

Slater, G. F., Lippmann-Pipke, J., Moser, D. P., Reddy, C. M., Onstott, T. C., Lacrampe-Couloume, G., et al. (2006). ${ }^{14} \mathrm{C}$ in methane and DIC in the deep terrestrial subsurface: Implications for microbial methanogenesis. Geomicrobiol. J. 23, 453-462. doi: 10.1080/01490450600875787

Sohlberg, E., Bomberg, M., Miettinen, H., Nyyssönen, M., Salavirta, H., Vikman, M., et al. (2015). Revealing the unexplored fungal communities in deep groundwater of crystalline bedrock fracture zones in Olkiluoto, Finland. Front. Microbiol. 6:573. doi: 10.3389/fmicb.2015.00573

Stępniewska, Z., Pytlak, A., and Kuźniar, A. (2013). Methanotrophic activity in carboniferous coalbed rocks. Int. J. Coal Geol.106, 1-10. doi: 10.1016/j.coal.2013.01.003

Stępniewska, Z., Pytlak, A., and Kuźniar, A. (2014). Distribution of the methanotrophic bacteria in the Western part of the Upper Silesian Coal Basin (Borynia-Zofiówka and Budryk coal mines). Int. J. Coal Geol. 130, 70-78. doi: 10.1016/j.coal.2014.05.003

Stolper, D. A., Lawson, M., Davis, C. L., Ferreira, A. A., Santos Neto, E. V., Ellis, G. S., et al. (2014). Formation temperatures of thermogenic and biogenic methane. Science 344, 1500-1503. doi: 10.1126/science.1254509

Stotler, R. L., Frape, S. K., Ahonen, L., Clark, I., Greene, S., Hobbs, M., et al. (2010). Origin and stability of a permafrost methane hydrate occurrence in the Canadian Shield. Earth Planet. Sci. Lett. 296, 384-394. doi: 10.1016/j.epsl.2010.05.024

Stotler, R. L., Frape, S. K., Ruskeeniemi, T., Ahonen, L., Onstott, T. C., and Hobbs, M. Y. (2009). Hydrogeochemistry of groundwaters in and below the base of thick permafrost at Lupin, Nunavut, Canada. J. Hydrol. 373, 80-95. doi: 10.1016/j.jhydrol.2009.04.013

Strąpó́, D., Mastalerz, M., Dawson, K., Macalady, J., Callaghan, A. V., Wawrik, B., et al. (2011). Biogeochemistry of microbial coal-bed methane. Annu. Rev. Earth Planet. Sci. 39, 617-656. doi: 10.1146/annurev-earth-040610-133343

Stroes-Gascoyne, S., and West, J. M. (1996). An overview of microbial research related to high-level nuclear waste disposal with emphasis on the Canadian concept for the disposal of nuclear fuel waste. Can. J. Microbiol. 42, 349-366. doi: 10.1139/m96-051

Suda, K., Ueno, Y., Yoshizaki, M., Nakamura, H., Kurokawa, K., Nishiyama, E., et al. (2014). Origin of methane in serpentinite-hosted hydrothermal systems: the $\mathrm{CH}_{4}-\mathrm{H}_{2}-\mathrm{H}_{2} \mathrm{O}$ hydrogen isotope systematics of the Hakuba Happo hot spring. Earth Planet. Sci. Lett. 386, 112-125. doi: 10.1016/j.epsl.2013. 11.001 
Sugimoto, A., and Wada, E. (1995). Hydrogen isotopic composition of bacterial methane: $\mathrm{CO}_{2} / \mathrm{H}_{2}$ reduction and acetate fermentation. Geochim. Cosmochim. Acta 59, 1329-1337. doi: 10.1016/0016-7037(95)00047-4

Takai, K., Moser, D. P., DeFlaun, M., Onstott, T. C., and Fredrickson, J. K. (2001). Archaeal diversity in waters from deep South African gold mines. Appl. Environ. Microbiol. 67, 5750-5760. doi: 10.1128/AEM.67.21.5750-5760.2001

Taran, L. N., Onoshko, M. P., and Mikhailov, N. D. (2011). Structure and composition of organic matter and isotope geochemistry of the Palaeproterozoic graphite and sulphide-rich metasedimentary rocks from the Outokumpu Deep Drill Hole, Eastern Finland. Geol. Surv. Finland 51, 219-228.

Taran, Y. A., Klinger, G. A., and Sevastianov, V. S. (2007). Carbon isotope effects in the open-system Fischer-Tropsch synthesis. Geochim. Cosmochim. Acta 71, 4474-4487. doi: 10.1016/j.gca.2007.06.057

Tazaz, A. M., Bebout, B. M., Kelley, C. A., Poole, J., and Chanton, J. P. (2013). Redefining the isotopic boundaries of biogenic methane: Methane from endoevaporites. Icarus 224, 268-275. doi: 10.1016/j.icarus.2012.06.008

Teske, A., and Biddle, J. (2008). "Analysis of deep subsurface microbial communities by functional genes and genomics," in Links Between Geological Processes, Microbial Activities and Evolution of Life, eds Y. Dilek, H. Furnes and K. Muehlenbachs (New York, NY: Springer Science+Business Media, B.V.), 159-176.

Thauer, R. K., Kaster, A., Seedorf, H., Buckel, W., and Hedderich, R. (2008). Methanogenic archaea: ecologically relevant differences in energy conservation. Nat. Rev. Microbiol. 6, 579-591. doi: 10.1038/nrmicro1931

Treat, C., Natali, S. M., Ernakovich, J., Iversen, C. M., Lupascu, M., McGuire, A. D., et al. (2015). A pan-Arctic synthesis of $\mathrm{CH} 4$ and $\mathrm{CO} 2$ production from anoxic soil incubations. Glob. Change Biol. 21, 2787-2803. doi: 10.1111/gcb.12875

Trinchero, P., Delos, A., Molinero, J., Dentz, M., and Pitkänen, P. (2014). Understanding and modelling dissolved gas transport in the bedrock of three Fennoscandian sites. J. Hydrol. 512, 506-517. doi: 10.1016/j.jhydrol.2014.03.011

Valentine, D. L., Chidthaisong, A., Rice, A., Reeburgh, W. S., and Tyler, S. C. (2004a). Carbon and hydrogen isotope fractionation by moderately thermophilic methanogens. Geochim. Cosmochim. Acta 68, 1571-1590. doi: 10.1016/j.gca.2003.10.012

Valentine, D. L., Sessions, A. L., Tyler, S. C., and Chithaisong, A. (2004b). Hydrogen isotope fractionation during $\mathrm{H}_{2} / \mathrm{CO}_{2}$ acetogenesis: hydrogen utilization efficiency and the origin of lipid-bound hydrogen. Geobiology 2, 179-188. doi: 10.1111/j.1472-4677.2004.00030.x

Västi, K. (2011). Petrology of the Drill hole R2500 at Outokumpu, Eastern Finland - the deepest drill hole ever drilled in Finland. Geol. Surv. Finland 51, 17-46.

Vovk, I. F. (1987). Radiolytic salt enrichment and brines in the crystalline basement of the East European Platform. Geol. Assoc. Canada 33, 197-210.

Walter, K. M., Zimov, S., Chanton, J. P., Verbyla, D., and Chapin, F. S. (2006). Methane bubbling from Siberian thaw lakes as a positive feedback to climate warming. Nature 443, 71-75. doi: 10.1038/nature05040
Wang, D. T., Gruen, D. S., Sherwood Lollar, B., Hinrichs, K.-U., Stewart, L. C., Holden, J. F., et al. (2015). Nonequilibrium clumped isotope signals in microbial methane. Science 348, 428-431. doi: 10.1126/science.aaa4326

Wang, J., and Wan, W. (2009). Factors influencing fermentative hydrogen production: a review. Int. J. Hydrogen Energ. 34, 799-811. doi: 10.1016/j.ijhydene.2008.11.015

Wang, Y., and Francis, A. J. (2005). Evaluation of microbial activity for long-term performance assessments of deep geologic nuclear waste repositories. J. Nucl. Radiochem. Sci. 6, 43-50. doi: 10.14494/jnrs2000.6.43

Ward, J., Slater, G., Moser, D., Lin, L., Lacrampe-Couloume, G., Bonin, A., et al. (2004). Microbial hydrocarbon gases in the Witwatersrand Basin, South Africa: implications for the deep biosphere. Geochim. Cosmochim. Acta 68, 3239-3250. doi: 10.1016/j.gca.2004.02.020

Wengel, M., Kothe, E., Schmidt, C. M., Heide, K., and Gleixner, G. (2006). Degradation of organic matter from black shales and charcoal by the wood-rotting fungus Schizophyllum commune and release of DOC and heavy metals in the aqueous phase. Sci. Total Environ. 367, 383-393. doi: 10.1016/j.scitotenv.2005.12.012

Whiticar, M. J. (1999). Carbon and hydrogen isotope systematics of bacterial formation and oxidation of methane. Chem. Geol. 161, 291-314. doi: 10.1016/S0009-2541(99)00092-3

Wouters, K., Moors, H., Boven, P., and Leys, N. (2013). Evidence and characteristics of a diverse and metabolically active microbial community in deep subsurface clay borehole water. FEMS Microbiol. Ecol. 86, 458-473. doi: 10.1111/1574-6941.12171

Zengler, K., Richnow, H. H., Rosselló-Mora, R., Michaelis, W., and Widdel, F. (1999). Methane formation from long-chain alkanes by anaerobic microorganisms. Nature 401, 266-269. doi: 10.1038/45777

Zhang, S., Mi, J., and He, K. (2013). Synthesis of hydrocarbon gases from four different carbon sources and hydrogen gas using a gold-tube system by Fischer-Tropsch method. Chem. Geol. 349-350, 27-35. doi: 10.1016/j.chemgeo.2013.03.016

Zhu, Y., Shi, B., and Fang, C. (2000). The isotopic composition of molecular nitrogen: implications on their origins in natural s accumulations. Chem. Geol. 164, 321-330. doi: 10.1016/S0009-2541(99)00151-5

Conflict of Interest Statement: The authors declare that the research was conducted in the absence of any commercial or financial relationships that could be construed as a potential conflict of interest.

Copyright (c) 2015 Kietäväinen and Purkamo. This is an open-access article distributed under the terms of the Creative Commons Attribution License (CC BY). The use, distribution or reproduction in other forums is permitted, provided the original author(s) or licensor are credited and that the original publication in this journal is cited, in accordance with accepted academic practice. No use, distribution or reproduction is permitted which does not comply with these terms. 